\title{
Plato Laws 3.680b-c: Antisthenes, the Cyclopes and Homeric exegesis
}

Lucia Prauscello

University of Cambridge

[Abstract] 111 words

In Laws 3, 680b-c the Athenian Stranger's positive evaluation of the Cyclopean 'way of life' (Od.9.112-15) is deeply indebted to Antisthenes' interpretatio Homerica of the Cyclopes as 'just' insofar they do not have the need of written law. Antisthenes' equation of 'need of law' with 'need of written law' is then contextualized within the unresolved tension, in the legislative project of the Laws, between oral dissemination ('proems' to the laws) and the potentially coercive power of the written text. Finally, Megillus' inept reply to the Homeric quotation by the Athenian Stranger allows us to gain a more nuanced view in the 'readerly' dynamics enacted by the internal audience of the Laws.

[Keywords] Antisthenes, Plato's Laws, Cyclopes, Homer

The nature and goal of Plato's engagement in book 3 of the Laws with what Barker, rather optimistically, called 'The Lessons of History',1 and the book's import for the Laws' overarching legislative project have been the subject of increasing scholarly interest in recent years. ${ }^{2}$ While sustained attention has mainly been paid to the properly historical parts of book 3 (682e8-693c5: the emergence and decadence of the Dorian states of Sparta, Argos and Messene; ${ }^{3}$ 693d1-698a8: Cyrus the Great's enlightened rule of Persia; 698a9-699d4: Athens' 'ancient constitution' at the time of the Persian Wars ${ }^{4}$ ), and to how they feed into the theoretical investigation of the principles of a healthy and stable 
constitution, the so-called 'archaeology' section (676a-682e) has attracted comparatively less interest. This is even more so for the Athenian Stranger's use of Homeric quotations (680b-c: Od. 9.112-15 and 681e: Il. 20.216-18) in the first part of book 3 to support his anthropological investigation into the early stages of human history. While previous scholarship has mostly focused on the Democritean resonances of this section, ${ }^{5}$ the aim of the present article is to explore some other unnoticed connections that underlie the first Homeric citation (Od.9.112-15) by the Athenian Stranger. A contextual analysis of the qualified positive assessment given by the Athenian Stranger to the Cyclopean

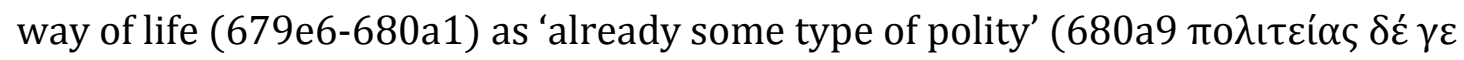

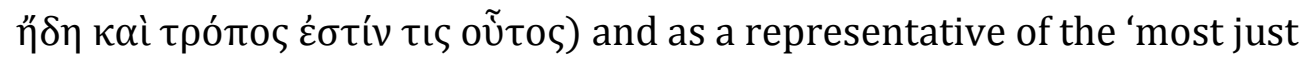

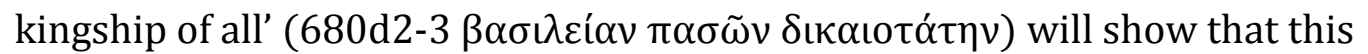
claim is less eccentric than previously supposed and that its root may be found in

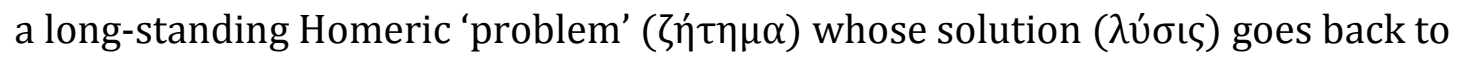
Antisthenes. The recovery of this Antisthenic link in the Athenian Stranger's mapping of the pre-history of human cultural evolution will also contribute to shedding further light on what has long been perceived by scholars as a major tension within the Laws: the rule of law, divided, as it is, between its inherent written nature and the need for a more flexible form of political advice and social control (the proems to the laws). ${ }^{6}$ Finally, at a more microscopic level, to introduce Antisthenes into the picture allows also for a more nuanced appreciation of Megillus' 'wrong' reply to the Athenian Stranger's quotation (680c6-d3), with consequences for the cultural world imagined to be inhabited by the internal audience of the Laws and its external readers (Sparta's literacy and its acquaintance with Homer). ${ }^{7}$ 
The beginning of book 3 (676a-b) signals a shift of focus in the investigation so far pursued by the Athenian Stranger: after the digression into the civic virtue of the individual citizen in books 1 and $2,^{8}$ the new theme will be 'the changing progression [i.e. through time] of cities to virtue or vice' (676a5-6

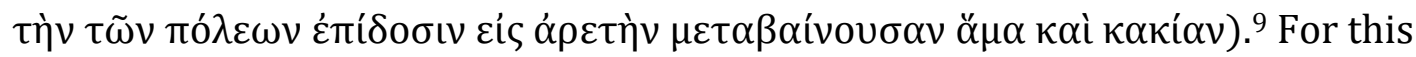
purpose the Athenian Stranger and his interlocutors will take as their vantage point 'an infinitely long period of time and the changes that occur in it' (676a8-

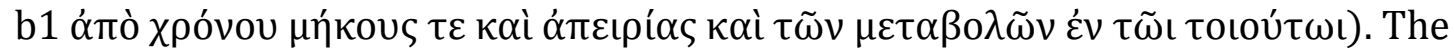
nature of historical causality with reference to political communities will thus be the guiding principle informing the new direction of the enquiry in book $3 .^{10}$ Once this agenda has been set, the Athenian Stranger establishes as a 'credible' premise (at least from the perspective of his interlocutors) ${ }^{11}$ the periodic occurrence of natural catastrophes ( $\varphi \theta 0 \rho \alpha i$ ) that, according to 'the ancient

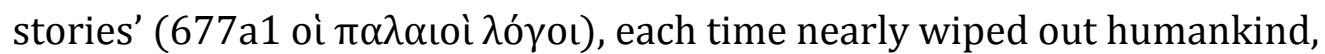
leaving alive only a small portion of it (677a4-6). ${ }^{12}$ The adoption of cyclic natural cataclysms as a heuristic template allows the Athenian Stranger to structure his anthropology of the early stages of human history in such a way that 'mythologising becomes an inescapable aspect of the investigation of the past' (Morgan 2013: 233).13

The myth of origin developed by the Athenian Stranger relies on the

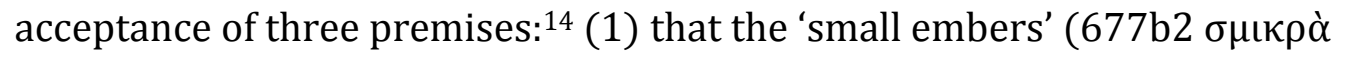
$\zeta \omega ́ \pi \cup \rho \alpha)$ of humankind rescued from the periodic destructions would each time live in small, isolated rural communities high up in the mountains, with scarce access to each other (677b); (2) that they would be shepherds (677e) and hunters (679a), feeding on milk and meat, ${ }^{15}$ resources that, if not plentiful, 
would anyway suffice for their livelihood so as to eliminate the need to compete for survival (678e-679a); (3) this primitive humankind would also have some basic technai, like clothing, pottery, housing and bedding (679a), but, most importantly, they would not have metals and metal-working (678d): as a consequence their society would be untouched by contemporary evils such as excessive riches or poverty, hubris, injustice, envy, stasis and war (679b-d). The defining feature of this primitive humanity is, according to the Athenian Stranger, its form of 'innocence' / 'simplicity' of character (679c2-3 $\alpha \gamma \alpha \theta$ oì $\mu \varepsilon \grave{v} v$

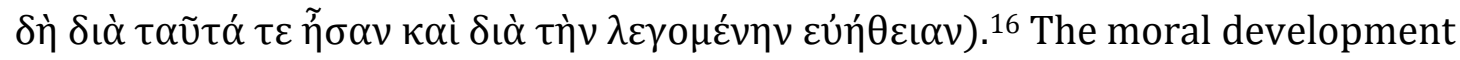
of this early humankind is still embryonic since at $678 \mathrm{~b} 1-3$ we are told that

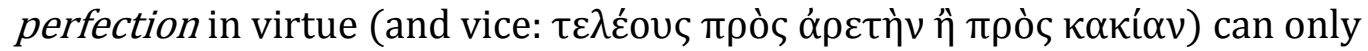
happen when humanity reaches a relatively advanced technological stage. ${ }^{17}$ Yet the inhabitants of this post-apocalyptic period do nevertheless possess some form, if impoverished, of virtue: 18 they are benevolently disposed towards each

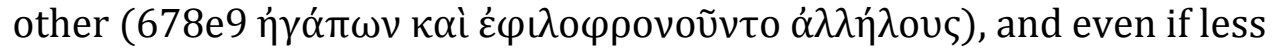
technologically advanced and more ignorant than the present or past

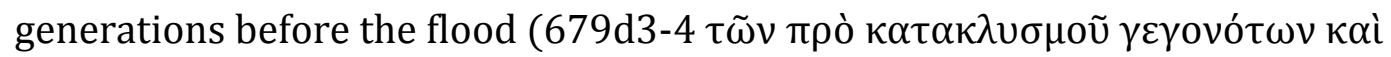

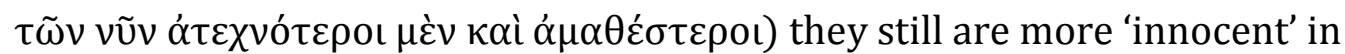
character, braver, more self-restrained and overall more just than later or earlier

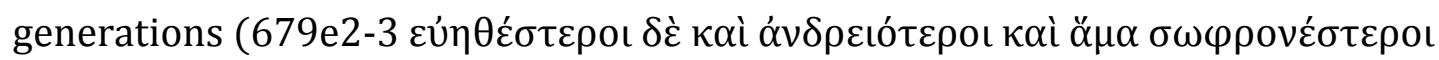

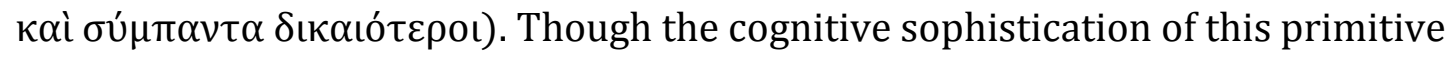
humankind is limited and openly acknowledged to be so by the Athenian Stranger (cf. 678b1-3 quoted above), the first survivors of the cyclic destructions do seem to have an intuitive, if underdeveloped, grasp of at least part of that 
'entirety of virtue' at which a lawgiver worth his name must aim (1.630e1-3 oúx

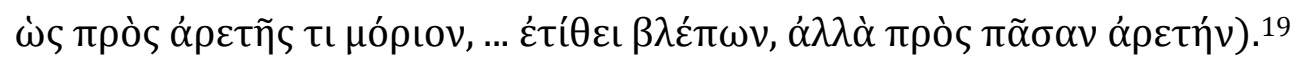

It is precisely at this initial stage of the Athenian Stranger's inquiry into the evolution of human society that Homer plays, as was to be expected, ${ }^{20}$ the lion's share in providing additional evidence, thanks to divine inspiration, for the alleged historical truth of the developmental account reported by the Athenian Stranger. ${ }^{21}$ To explain to his interlocutors the form of political association of this primitive humankind (dunasteia or patriarchy), the Athenian Stranger draws on Homer's description of the Cyclopean way of life: people living in a single

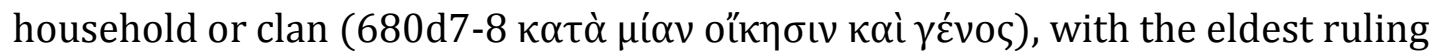
the entire household (680e1-2). The passage is worth quoting in full (679e6680a1):

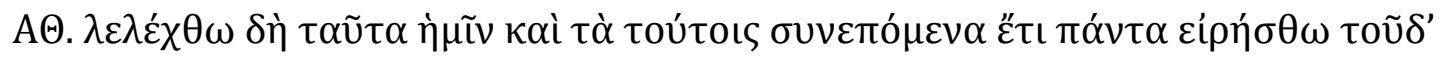

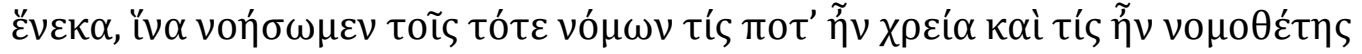

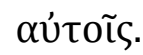

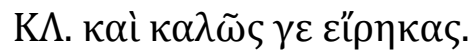

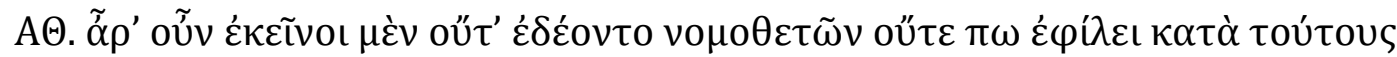

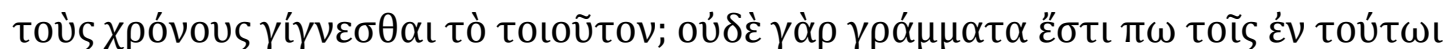

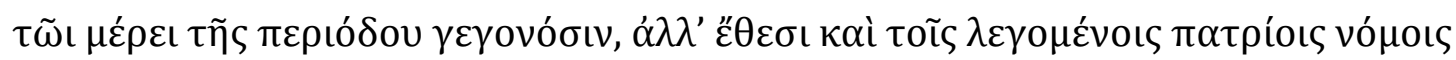

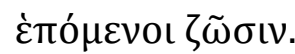

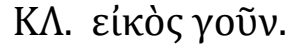

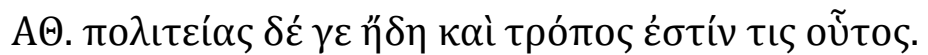

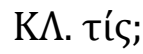




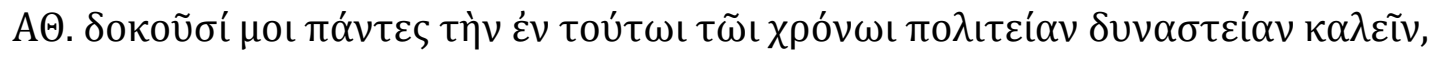

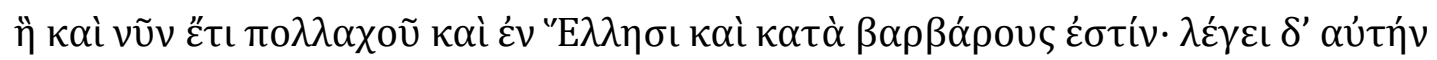

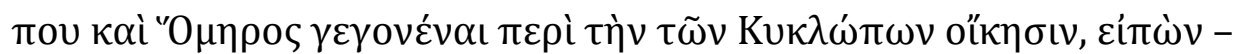

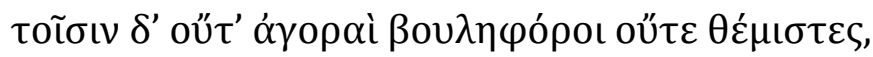

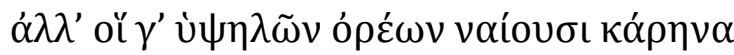

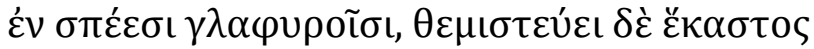

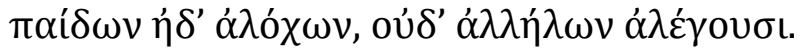

(Od. $9.112-15)$

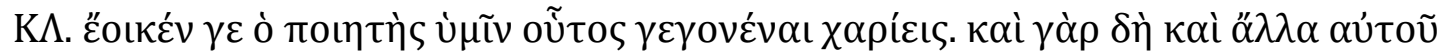

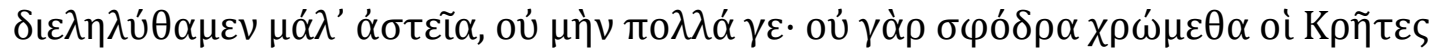

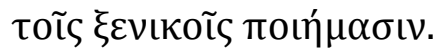

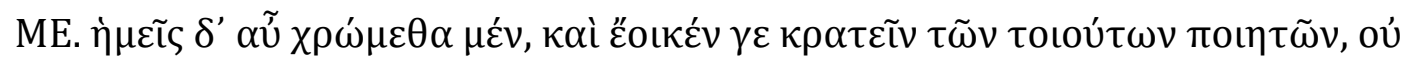

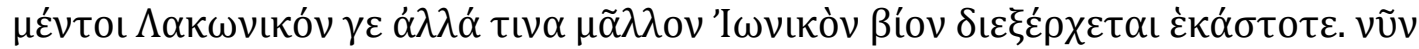

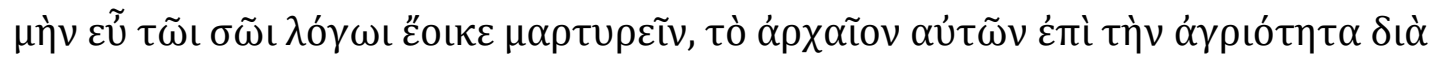

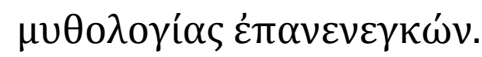

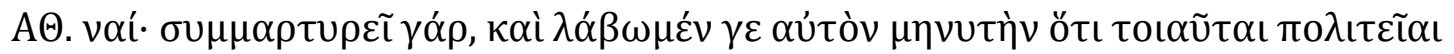

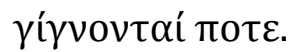

$\mathrm{K} \Lambda . \kappa \alpha \lambda \tilde{\omega} \varsigma$.

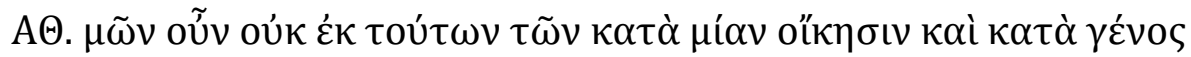

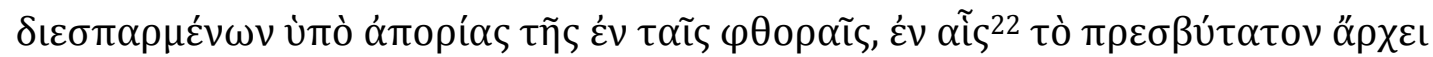

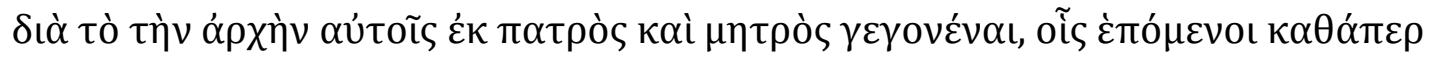

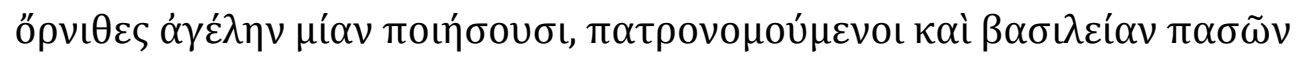

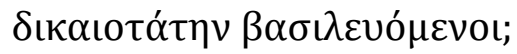




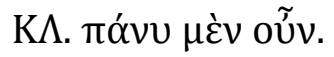

ATHENIAN STRANGER: What we have said so far and all that follows from it, let it be said for this reason, so that we may understand whatever need of laws the men of that time had and who was their lawgiver.

CLEINIAS: You have put it well.

ATHENIAN STRANGER: Is it not the case that those humans had no need of lawgivers and that in those times such a thing (i.e. the law) ${ }^{23}$ was not inclined to come into existence? For those born in that period of the cycle did not yet have but they lived in obedience to habits and the so-called ancestral customs. CLEINIAS: This is at least likely.

ATHENIAN STRANGER: But this too is already a type of polity.

CLEINIAS: Which one?

ATHENIAN STRANGER: Everyone seems to me to call the polity that then existed dunasteia, and it still exists now in many places among both Greeks and barbarians. Homer too, I suppose, says that it exists, when he says concerning the household system of the Cyclopes:

they do not have assemblies to take council nor ordinances, but they dwell on the top of lofty mountains in hollow caves and each rules over his children and wives, and they do not trouble themselves about one another.

(Od. 9.112-15) 
CLEINIAS: This poet of yours seems to have been charming. For we have also gone through other verses of his that were very refined, but not very many, at any rate: for we Cretans do not make much use of foreign poetry.

MEGILLUS: But we Spartans do and consider him the best among such poets; however, the way of life he describes each time is not Laconian but rather Ionian of some sort. And in the present circumstances he seems to bear good witness to your claim by referring the primitive ways of the Cyclopes, in his storytelling, to their savagery.

ATHENIAN STRANGER: Yes, for he supports us with his testimony; let us take him, at any rate, as evidence that such polities do sometimes arise. CLEINIAS: Fine.

ATHENIAN STRANGER: So, did not these forms of polities arise out of these people who had been scattered in single households and in separate families by the dearth of resources that occurred in the periods of destruction? And is it not the case that in these communities the eldest ones rule because the authority comes to them from their parents, and that, by following them, they will form, as birds do, a single flock, ${ }^{24}$ being ruled by paternal authority ${ }^{25}$, that is, ${ }^{26}$ by a kingship that is the most just of all?

CLEINIAS: Very true.

Plato's commentators have usually either passed over the Homeric quotation by the Athenian Stranger in silence, ${ }^{27}$ or have limited themselves to noting that $O d$. 9.114-15 is also cited by Aristotle in Politics $1252 \mathrm{~b} 22-24^{28}$ to exemplify, as in Plato, the role of patriarchal communities within human society. ${ }^{29}$ Recent exceptions are Dušanić's attempt to see in the Homeric Cyclopes a veiled allusion 
to Macedonian power via Dem. 18.6730 and Dillon's suggestion that at Laws 680b we are dealing with a perversely ironical quotation of Homer by Plato, thus emphasizing the deep-seated ambiguity of the Golden Age myth. ${ }^{31}$ Both interpretations seem to me unsatisfactory. Even leaving aside the fact that the supposed verbal link between our passage of the Laws and Dem. 18.67 is of the flimsiest (the occurrence of the term dunasteia in both passages), Dušanić entirely neglects the fact that the Cyclopean way of life is introduced at 680b-c by the Athenian Stranger to illustrate the form of political association enjoyed by the primitive and virtuous humanity described at 677a-679e. As for Dillon's interpretation, while there is no doubt that Cleinias and Megillus' reaction to the Homeric quotation implies some ironic and condescending banter on the part of the Athenian Stranger, ${ }^{32}$ the very fact that some of same Homeric lines are cited also by Aristotle, via Plato, in his Politics to make an analogous point seems to me to reduce significantly the possibility that Plato is here spectacularly redeploying Homer against Homer, so to speak. ${ }^{33}$

We have already observed that the Athenian Stranger introduces the 'Cyclopean way of life' not as an example of the spontaneous and bountiful generosity of nature in a distant Golden Age or as a paradigm of hubristic, subhuman behaviour, ${ }^{34}$ but on the contrary as an illustration of the form of political association of a primitive humankind that is 'simpler, braver, more selfrestrained and overall more just' than past or present generations of men ( $c f$. 679e2-3). According to the Athenian Stranger's version, this early humanity can

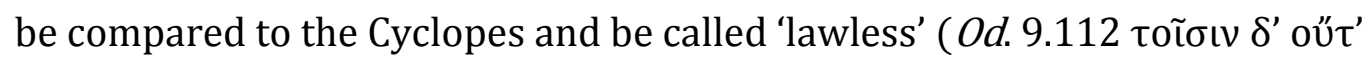

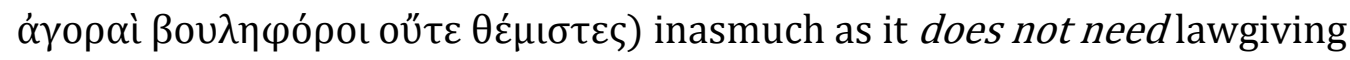
because of its tendencies towards virtuous behaviour: the need for laws simply 
does not apply to these early humans (cf. 680a1 for the $\chi \rho \varepsilon i ́ \alpha$ motif and 680a3-4

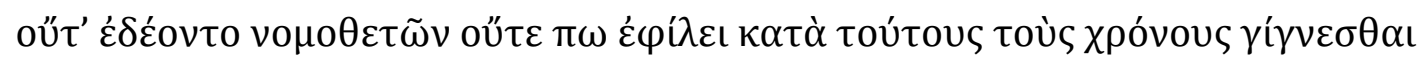

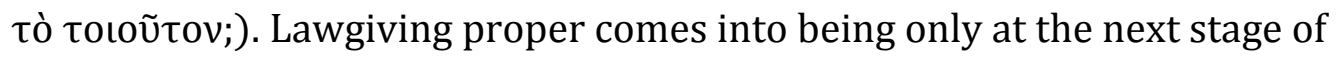
human evolution (680e6-681d6): the scattered households congregate to farm

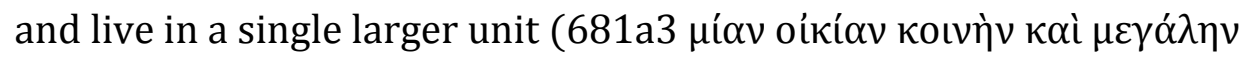

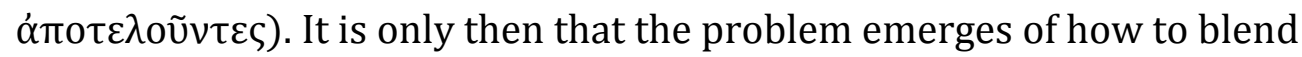
different traditions and how to distribute powers: ${ }^{35}$ chosen representatives (681c8 koเvoús) will then review the rules of all the families and propose rules that recommend themselves for common use (681c7-d5). ${ }^{36}$ These representatives will thus be called nomothetai(681d2). ${ }^{37}$ Furthermore, at 680a5-7 we are also told that the early humans who survived the flood do not have laws because they do not yet have writing, hence their reliance on ancestral

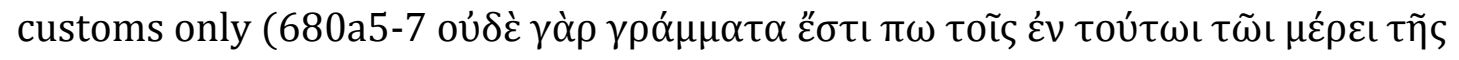

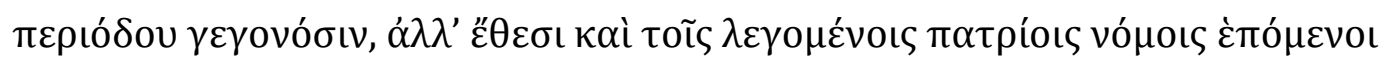
$\zeta \tilde{\omega} \sigma \mathrm{v}) \cdot{ }^{38}$

If we bear in mind this connection between justice, absence of the need of law and absence of writing with relation to the early stages of humankind, a more productive way of making sense of why the Cyclopes are brought into the picture by the Athenian Stranger precisely at this stage of the evolutionary ladder is offered to us by the Homeric scholia to Od. 9.106. ${ }^{39}$ The text of the scholia THMVd to Od. 9.106 is the following: ${ }^{40}$

(T1) Scholium T ad Od. ı 106 (= Schrader pp. 86,14-87,10)= Antisthenes SSRV A 189, ll. 1-14 (= F 53 Decleva Caizzi) 


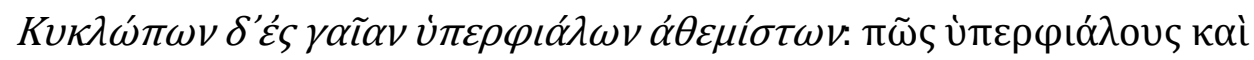

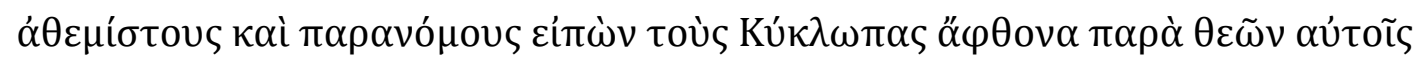

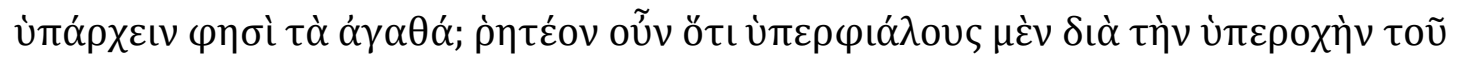

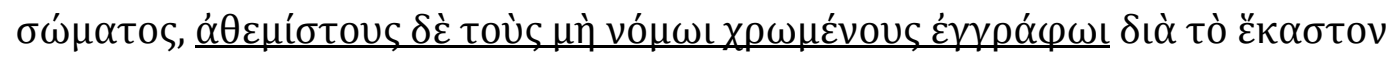

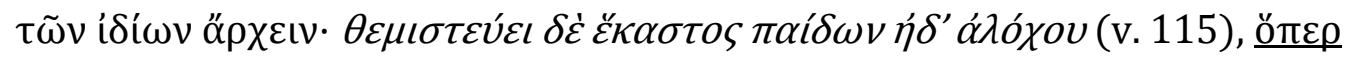

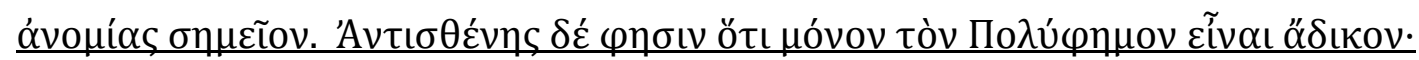

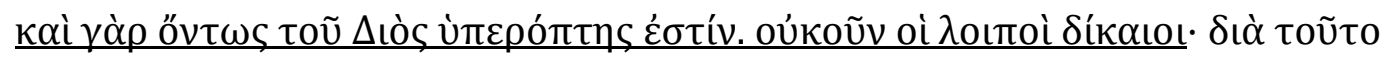

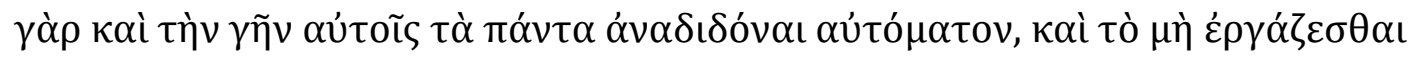

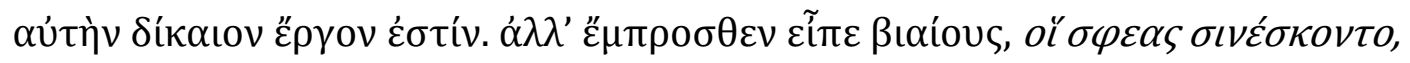

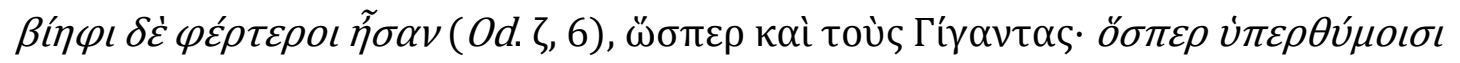

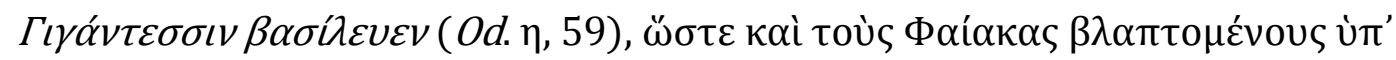

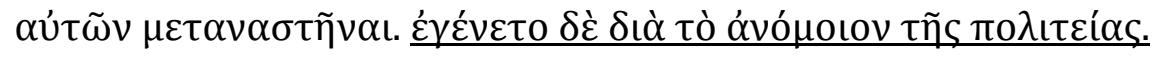

to the land of the Cyclopes who are hyperphialoi and athemistoi: how can [the poet] call the Cyclopes arrogant, lawless and transgressing the law and then say that the gods grant them unbegrudgingly the goods [of nature]? We must then say that he called them hyperphialoi because of the excessive size of their bodies $^{41}$ and athemistoi inasmuch as they do not make use of written laws

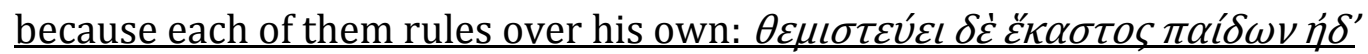
ádóxov (v. 115), which is evidence of their lack of laws. Antisthenes says that only Polyphemus is unjust, for he truly despises Zeus. Surely then the others are just. ${ }^{42}$ For it is because of this [i.e. their justice] that the earth produces everything spontaneously for them and the fact that they do not plough the land is thus an act of justice. But previously [the poet] called them violent: '[the Cyclopes] who plundered them [the Phaeacians] since they were stronger' (Od. 
8.6), and so he called also the Giants: '[Eurymedon] who rules over the overweening Giants', so that the Phaeacians too, being hurt by them, had to relocate elsewhere. This happened because of the different nature of their (i.e. the Cyclopes') political organisation. ${ }^{43}$

(T2) Scholium M ad Od. ı 106 (= Schrader p. 86 in his apparatus)

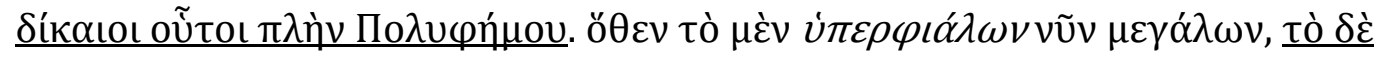

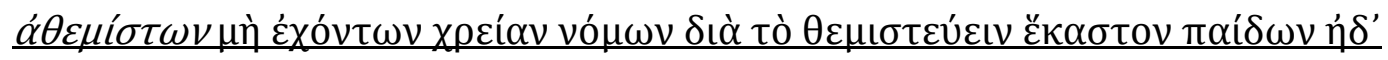

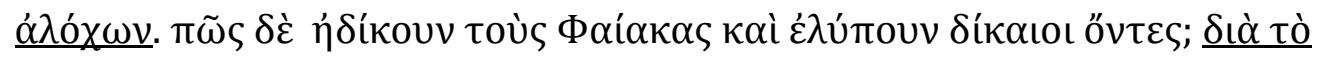

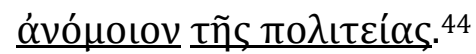

These were just except Polyphemus. Hence the word hyperphialōn refers now to those who are big and the word athemistonn to those who do not have need of laws because each rules over his own children and women. But how is it that the Cyclopes, if they were just, did wrong and harmed the Phaeacians? Because of their different political organisation.

(T3) Scholium H ad Od. ı 106 (= Schrader p. 87, 11-13)= Antisthenes SSRV A 189, ll. 15-17

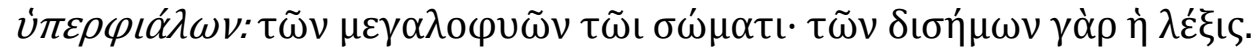

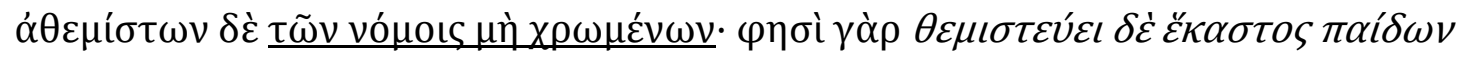

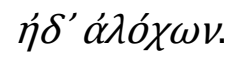


hyperphialōn: those who have a big body by nature, for the word is one of those which can have two meanings. athemistōn: those who do not use laws, for [the poet] says 'each rules over their own children and women.'

(T4) Scholium Vd ad Od. 1106 (=Schrader pp. 87, 13-17, and 87, 21-88, 8) = Antisthenes SSRV A 189, ll. 17-39.

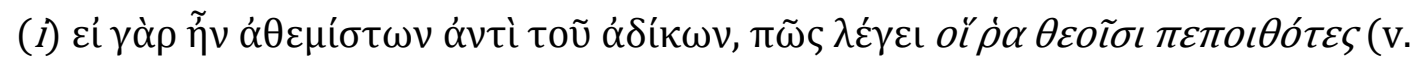

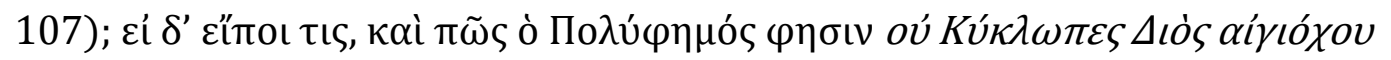

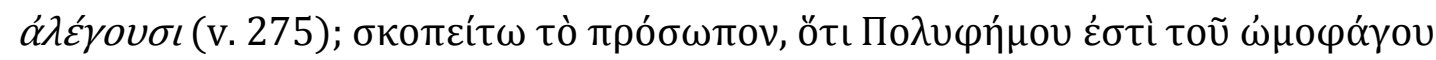

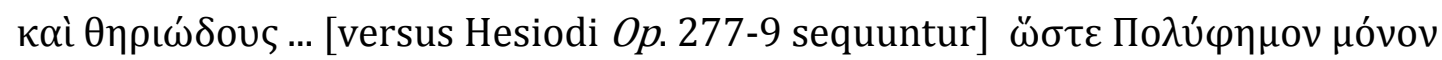

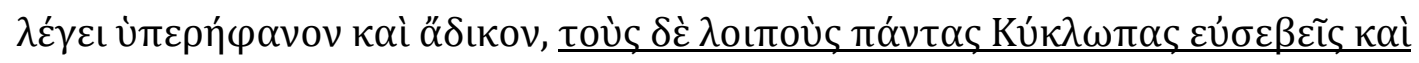

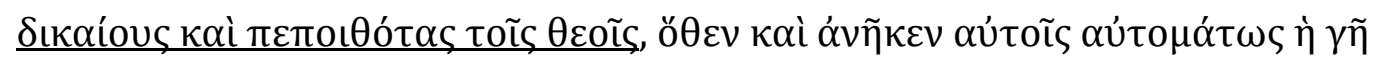

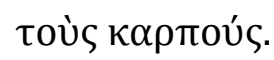

for if athemistōn stood for 'unjust', why does the poet say of them 'who trust in the gods' (v. 107); but if someone were to say, 'And how is it that Polyphemus says 'the Cyclopes do not care about aigis-bearing Zeus' (v. 275)?' Let him consider the question from the point of view of the speaking character: that of Polyphemus, who eats raw flesh and is as wild as a beast ... so that [the poet] calls Polyphemus, and him only, arrogant and unjust, but all the other Cyclopes pious, just and trusting in the gods. And this is the very reason why the soil spontaneously produces fruits for them. 


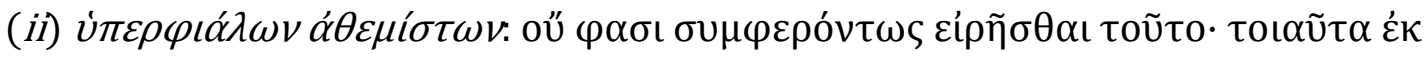

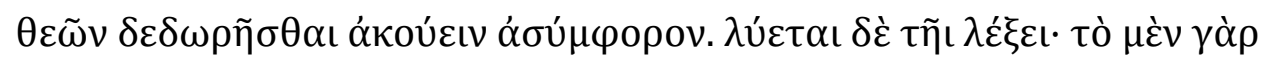

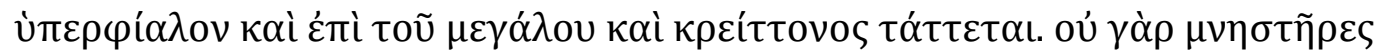

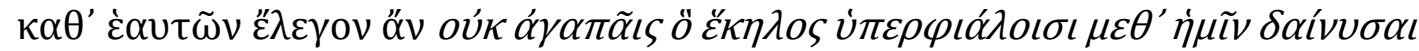

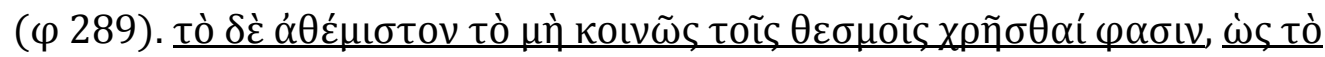

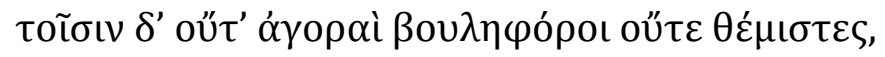

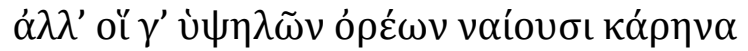

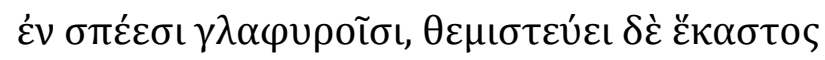

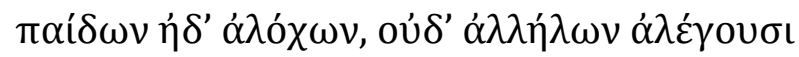
( 112 sqq.)

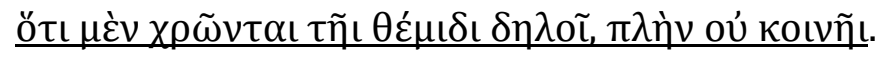

hyperphialōn athemistōn: they say that this [i.e. the choice of the expressions hyperphialōn and athemistōn] has not been said properly: it is unbecoming to read that the gods granted them such gifts. But the problem is solved if we take into account the linguistic usage: for the term hyperphialos is applied also to what is big and more powerful; otherwise the suitors could not have said of themselves 'Are you not content that you are feasting undisturbed in our company, we who are hyperphialoi?' As to the term athemistos, they say that it means 'to make no use of shared ordinances', for the lines ... clearly show that the Cyclopes do use ordinances, but not commonly shared ones. 
(T5) Scholium Vd ad Od. ı 115 (= Schrader p. 88, 9-17) = Antisthenes SSRV A 189, ll. $40-47$

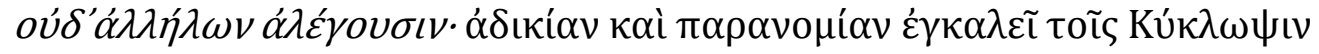

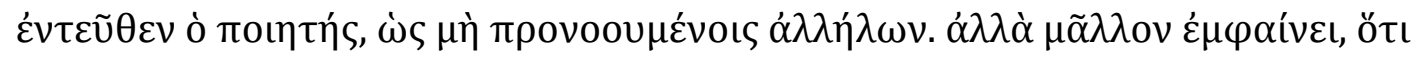

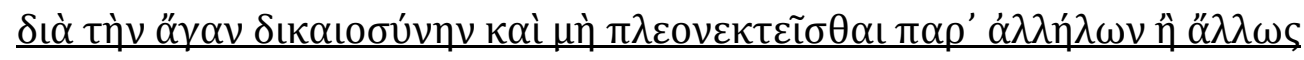

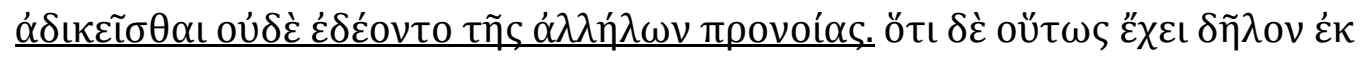

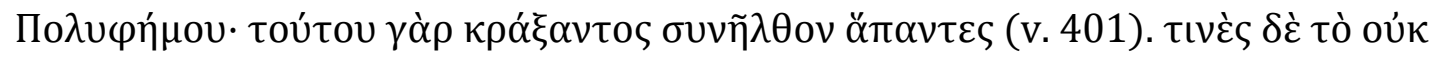

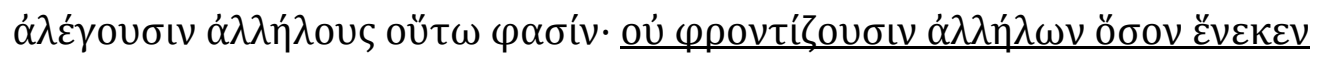

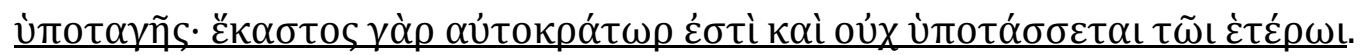
they do not care for each other: here the poet charges the Cyclopes with lack of justice and unlawfullness as if they did not have forethought for each other. But [in using these words] the poet rather indicates that it is because of their great $\underline{\text { sense of justice and of not taking advantage over each other or being wronged in }}$ any other way that they did not even need to have forethought for each other. That this is the case is clear from Polyphemus: for when he cries out, everyone comes together (1. 401). Some take the expression 'they do not care for each other' to mean the following: they do not worry about each other inasmuch as rank is concerned; for each is master of his own and is not subject to anyone else.

The Antisthenic origin of the whole section of the scholia THMVd to Od.9.106 about the 'justice' of the Cyclopes has long been recognized by both Homeric and presocratic scholars. ${ }^{45}$ If we believe the scholia, it is Antisthenes who first 
systematically championed a positive view of the way of life of the Cyclopes,

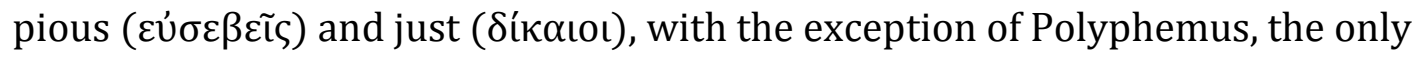
villain. It is also Antisthenes that first linked the 'lawlessness' of the Cyclopes to

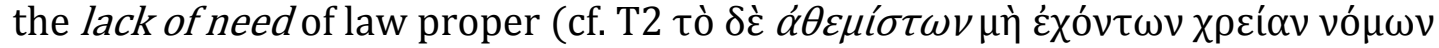

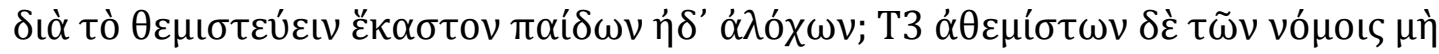

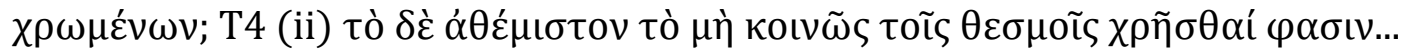

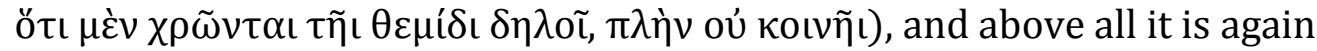

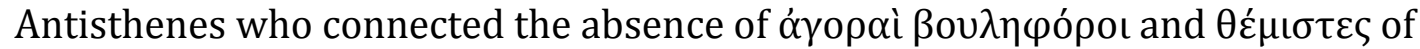

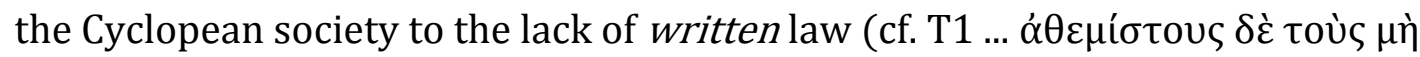
vó $\left.\mu \omega \iota \chi \chi \omega \mu \varepsilon \varepsilon_{v o u} \varepsilon \dot{\gamma} \gamma \rho \alpha \dot{\alpha} \varphi \omega \mathrm{l}\right)$. While hunting for traces of Antisthenic resonances in Plato's writings is not an unknown exercise among modern scholars, ${ }^{46}$ the specific Antisthenic echo of our passage has so far escaped the attention of critics. ${ }^{47}$ Laws $3.680 \mathrm{~b}-\mathrm{c}$ should thus find its place among the testimonia of Antisthenes' early (if not almost-contemporary) reception in the fourth century BC. The fact that Plato has the Athenian Stranger quoting Od. 9.112-15 in the 'archaeological' section of his human history to exemplify the pre-political set up of a primitive and virtuous humankind does suggest that Antisthenes' interpretatio homerica of the Cyclopes already had some currency among Plato's potential readers, at least the most alert ones. And it is indeed on the sophistication and alertness (or lack thereof) of Megillus as a Homeric reader

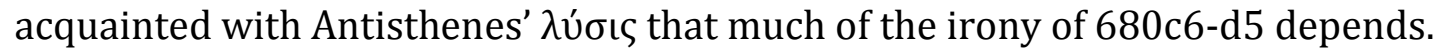
But before unravelling the narrative strategy underlying the Athenian Stranger's exchange with Megillus qua Homeric reader, let us first dwell briefly on the significance of this Antisthenic echo for the legislative project of the Laws as a whole. The link between the rule of law and written legislation is of 
paramount importance for Plato's political agenda in the Laws. ${ }^{48}$ in the secondbest city, writing qua political medium is explicitly rehabilitated by Plato ${ }^{49}$ and the future inhabitants of Magnesia will literally have the Laws as their 'prescribed' school-book (7.811e5-812a1). The written text of the Laws itself will be both the training text of the future Magnesian teachers, who must understand it and approve of it, and the textbook of the pupils (811e5-6 kai

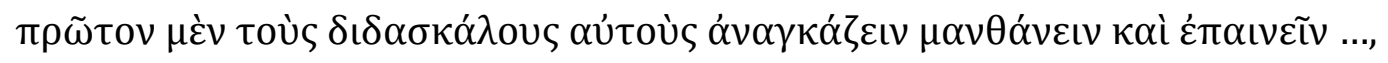

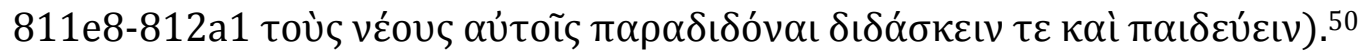
Further on at 10.890e6-891a4 Plato has the Cretan Cleinias suggesting that the writing medium is 'in a sense the greatest help for an intelligent legislation' (каі

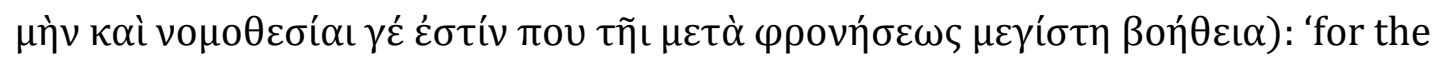

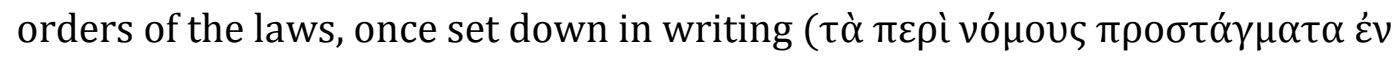

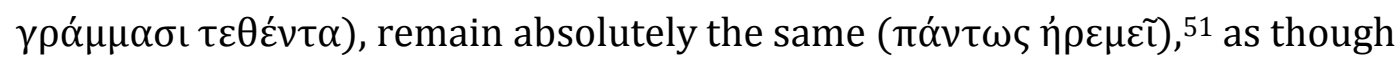

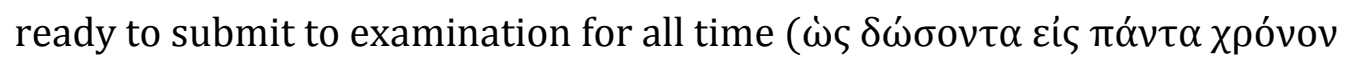

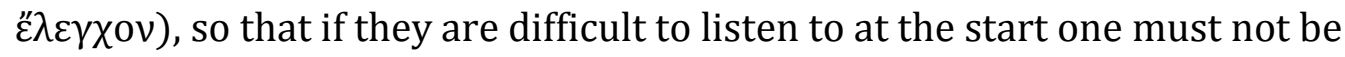
afraid, since even a slow learner will be able to go back to examining them

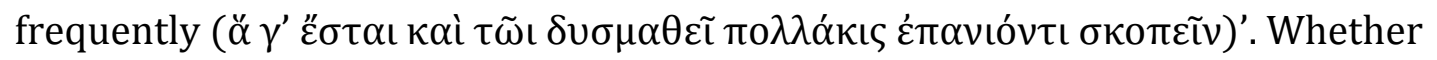
we are inclined or not to take seriously Cleinias' 'political' defence of writing, 52 what nevertheless makes it feasible within the communicational networks of the second-best city is that in Magnesia the legislator will have authorial control over the reception and dissemination of his text. Part of Socrates' critique of writing in the Phaedrus was directed not only towards the dialectic 'passivity' of writing as a medium (275d) but also towards the possibility of misinterpretation generated by a process of transmission that is virtually open-ended — an open-endedness that enables the text to reach equally the 'informed' and the ignorant or biased 
readers $(275 e 1-5) .53$ The process of circulation envisaged by Plato's Socrates, in the Phaedrus, presupposes unfavourable conditions of dissemination, fostered

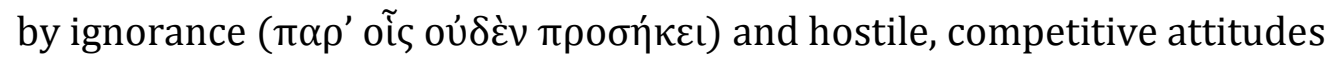

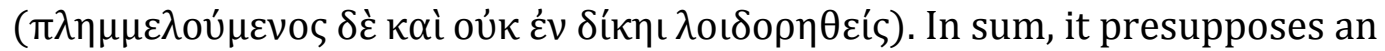
agonistic scenario of competing written discourses, each pitched at each other's interpretation. But this will not be the case in Magnesia where 'the writings of

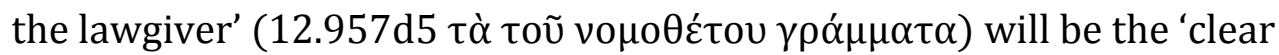

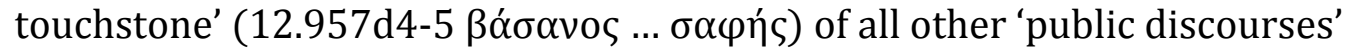

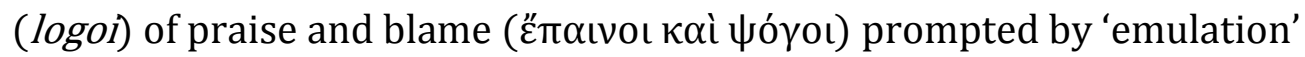
(philonikia) be they in verse or prose, written or oral (12.957d1-3). The discourse of the law will thus be like an 'antidote to the other speeches'

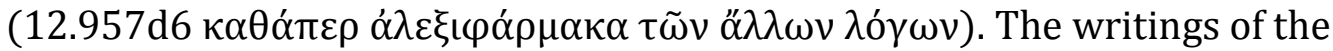
lawgiver will not be in competition with other writings. ${ }^{54}$ The untrained, reckless nature of the audience as envisaged in the Phaedrus is not a psychological condition that can be predicated of the Magnesian citizens-to-be: they will have been properly 'trained' to be responsive and attentive to the legislator's law and his purpose via the oral'fiction' of the proems to the laws. ${ }^{55}$

To go back to where we started: Plato's specific commitment, in the Laws, to writing as a political medium finds in Antisthenes' equation of 'need of law' with 'need of written law' a useful ally for his pessimistic view of the corrupting influence of political power in historical societies. The necessity of the rule of written law is a second-best option (the first being knowledge) because of the inherent defectiveness of human nature when confronted with power (9.874e7875d5). Only a primitive humanity which, by a combination of environmental factors and moral outlook, was inherently 'more just' than historically developed 
societies could survive without the need (chreia) of written laws. This is a paradoxical consequence of the unresolved tension, in the Laws, between the coercive power of the written law and its oral dissemination through the 'proems': in Plato's Magnesia the very same 'habits and so-called ancestral customs' (3.680a6-7), which informed the 'just' life of the first human community to survive the flood, will be co-opted as part of the new law-code through the textuality of the Laws itself as a written oeuvre. ${ }^{56}$

Let us now turn to the response of the internal audience of the Laws, Cleinias and Megillus, to the Athenian Stranger's quotation and use of Homer's Od. 9.112-15. Martin has recently shown how in Plato's Laws the 'citation and manipulation of Homeric poetry and poetics' is central to the structure of the Laws itself. ${ }^{57}$ Part and parcel of Homer's paradoxical 'hidden centrality' in the Laws is 'the shocking realisation that for some Greeks in antiquity, Homer was a distant country'. ${ }^{58}$ This point is very strongly brought home at 680c2-d5: both Cleinias and Megillus, though broadly agreeing with the Athenian Stranger's conclusion, ostensibly fail to engage in any detail with his use of the Homeric citation. Whereas Cleinias' comment on the Cretans' casual acquaintance with

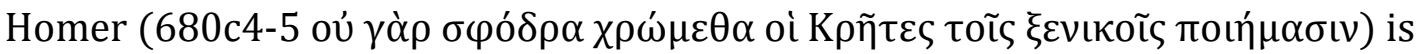
briefly and humorously articulated through standard terms of literary criticism

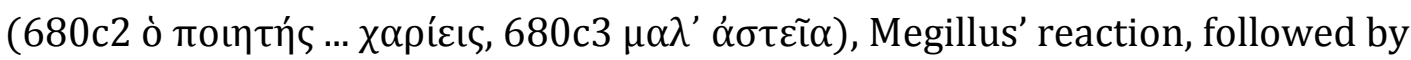
the Athenian Stranger's rejoinder, is more complex and requires some unpacking (see above 680c6-d5).

In particular, two features of Megillus' reply deserve attention: while acknowledging the primacy of Homer as a poet and his diffusion at Sparta, Megillus (i) immediately connects the Homeric poems with 'a way of life' that is 
more Ionian than Spartan and (ii) links the primitive ways of life of the Cyclopes

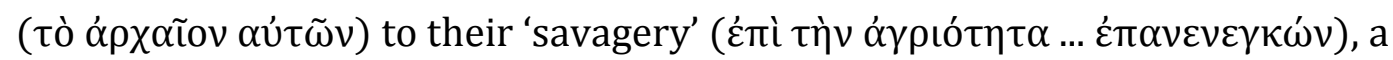

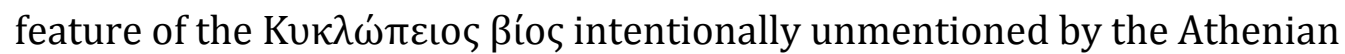
Stranger. As to (i), Martin has connected this passage - rightly, in my view with Plut. Lyc. 4.3-4, where we are told that during his journeys Lycurgus sailed from Crete to Asia, with the aim of comparing the Cretan civilization, simple and severe, with that of the Ionians, extravagant and luxurious. (Plut. Lyc. 4.3

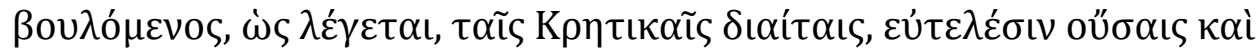

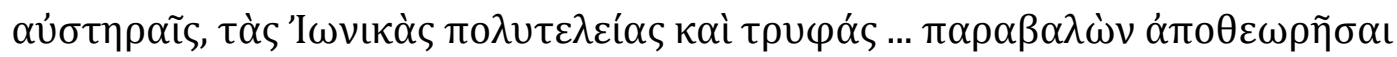

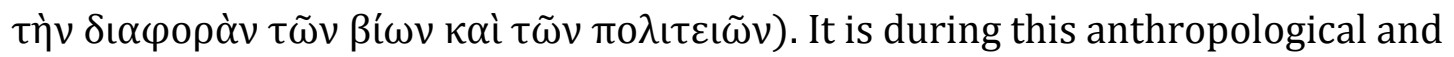
'nomological' quest that Lycurgus first encounters the text of Homer at Samos via

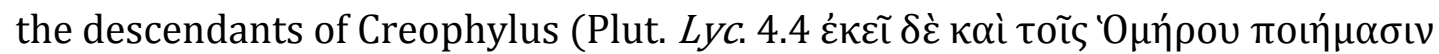

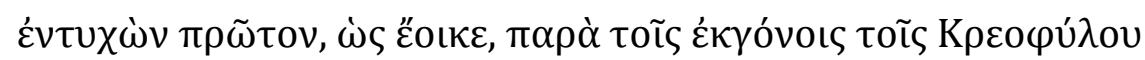
$\delta\llcorner\alpha \tau \eta \rho o u \mu \varepsilon ́ v o ı \varsigma)$. Lycurgus, we are told, recognized that the political and educative lessons of the Homeric text were not inferior to the part dedicated to

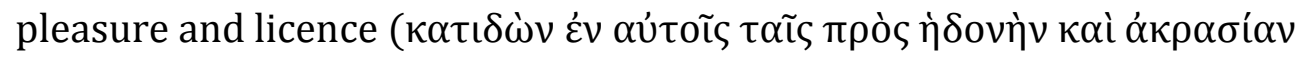

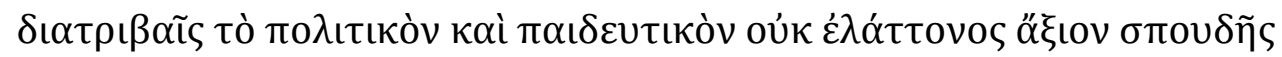
$\left.\alpha_{\alpha} \alpha \mu \varepsilon \mu \gamma \mu \varepsilon \varepsilon^{\prime} v v\right)$. Hence, the Spartan lawgiver eagerly copied the Homeric text in

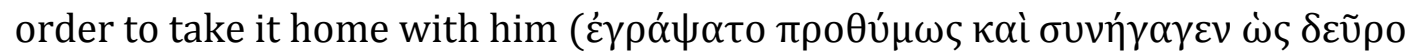

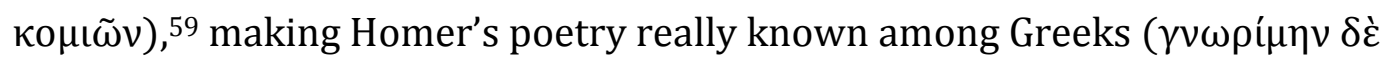

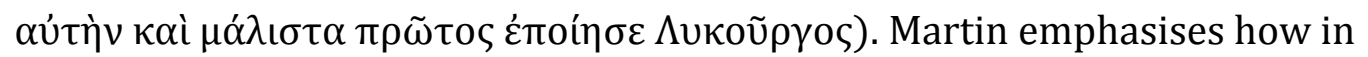
Megillus' reply Lycurgus is deliberately 'gapped out' by Plato the author over the head of Megillus the character, inasmuch as Lycurgus 'is not celebrated for the promotion of Homer as a way to benefit his polis with political and educational lessons'.60 This may be part of the Athenian Stranger's strategy, but there is also 
another possible inference to be drawn from the comparison between Plutarch's Life of Lycurgus and Plato's Laws 3, 680c6-d5. As is well known, two different versions of Lycurgus' 'encounter with Homer' are attested in our sources: ${ }^{61}$ either Lycurgus did meet Homer in person ${ }^{62}$ - and in this strand of the tradition we hear nothing specific about the transmission and dissemination of the Homeric text as such - or he is said to have imported the Homeric poems to Sparta via Samos and the Creophylean guild. 63 The origin of this second version is debated, ${ }^{64}$ but scholars seem to be unanimous in considering the Peripatetic Heraclides Lembus (second century BC) our earliest extant witness for this strand of the tradition before Plutarch (Her. Lemb. Excerpta politiarum 10 Dilts $\approx$ Arist. fr. 661.10 Rose = F 107 Gigon). ${ }^{65}$ As acknowledged by Martin, Laws 3, 680c6-d5 does leave plenty unsaid (no mention of Lycurgus and his journey to Ionia). Yet the specific connection established by Megillus between Homeric poetry and an Ionian way of life (rather than a Spartan) seems, at least to me, to suggest that Plato did mean (albeit selectively) to refer to - and to be understood by his external audience as referring to - that second strand of the tradition. ${ }^{66}$ Irrespective of whether we believe this tradition to be genuinely archaic or not, and of the topicality of the association between mythical

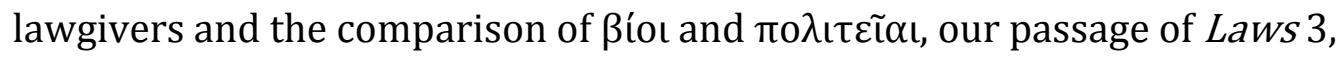
680c6-d5 stands a plausible chance as candidate for a reflection of the early reception of Lycurgus' encounter with the Homeric text, together with Heraclides Lembus.

But what about Megillus' interpretation, not of Homer in general, but of

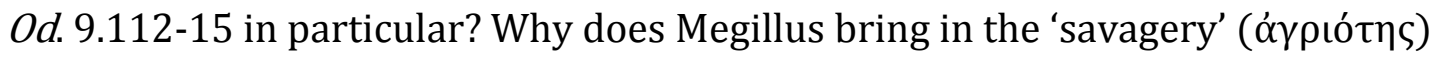
of the Cyclopes? Already Weil noticed that, strictly speaking, there is nothing 
specific about the Cyclopes' savagery in the Homeric quotation by the Athenian Stranger, and very little anyway in book 9 of the Odyssey. ${ }^{67}$ According to Weil, the explanation for Megillus' blundering answer should be sought in Plato's willingness to make of Megillus 'un exemple de "critique du document" et d'interprétation historique': 'Mégillos a cru trouver chez Homère un raisonment — qui n'y est pas. L'Athénien écarte ce raisonnement, et en revient à un fait précis. C'est exactement la méthode de Thucydide, qui trouve dans Homère des “indices" de fait' (Weil 1959: 71). I would like to suggest that Megillus is here being exposed by the Athenian Stranger ${ }^{68}$ also, if not mainly, as a naive reader of Homer who has not understood Antisthenes' interpretatio homerica of the Cyclopes, as presupposed by the Odyssey quotation at $680 \mathrm{~b}-\mathrm{c} .{ }^{69}$ One of the

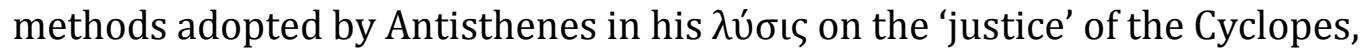
along other standard ones (linguistic usage and semantic variation: T4 (ii)

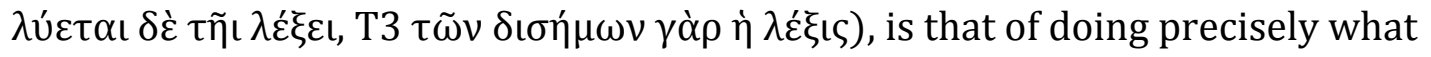
Megillus has not been able to do in his capacity as Homeric reader: to distinguish

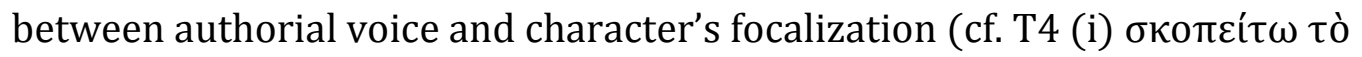

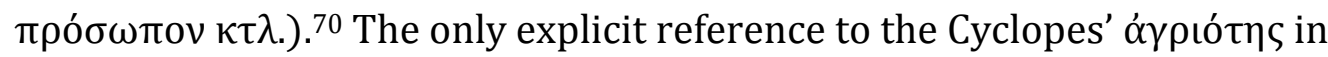
Odyssey 9 is voiced by Odysseus, as a self-interested narrator of his apologos to

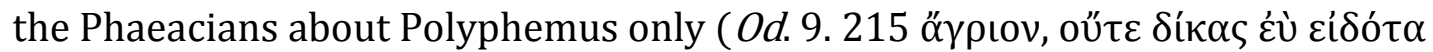

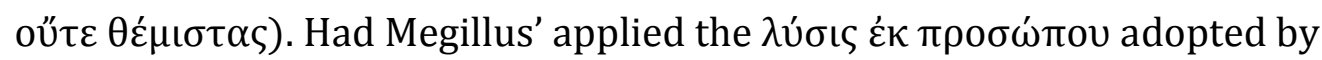
Antisthenes, he would not have drawn a wrong inference about the societal standards of the Cyclopean society. Megillus' maladroit answer, and his lack of proficiency as an alert Homeric reader acquainted with the most recent trend of literary criticism is a further way in which Plato, via the Athenian Stranger, represents Homer and his poetry as 'an overtly Athenian possession'. ${ }^{71}$ To 
identify Antisthenes' interpretatio homerica of the Cyclopes as the conceptual framework exploited by the Athenian Stranger in his quotation of Od.9.112-15 allows us both to make better sense of the purpose and aim of the quotation itself, within the broader structure of the Laws, and also to gain a more nuanced view of the 'readerly' dynamics enacted by the internal audience of the Laws.

\section{Bibliography}

Adomènas, M. (2001) 'Self-reference, textuality, and the status of the political project in Plato's Laws', OSAP21, 29-59

Atack, C. (2014) Debating Kingship: Models of Monarchy in Fifth-and FourthCentury BCE Greek Political Thought (unpublished PhD thesis, University of Cambridge)

Bakker, E.J. (2013) The Meaning of Meat and the Structure of the Odyssey (Cambridge)

Barker, E. (1918) Greek Political Theory: Plato and His Predecessors (London) Bertrand, J.-M. (1999) De l'écriture à l'oralité: lectures des Lois de Platon (Paris) Bobonich, C. (1996) 'Reading the Laws', in C. Gill and M.M. McCabe (eds), Form and Argument in Late Plato (Oxford and New York) 249-82

- (2002) Plato's Utopia Recast: His Later Ethics and Politics (Oxford)

Brancacci, A. (1990) Oikeios logos: la filosofia del linguaggio di Antistene (Naples)

Brisson, L. and Pradeau, J.-F. (2006) Platon: Les Lois, Livres I à VI (Paris) 
Cassio, A.C. (2002) 'Early editions of the Greek epics and Homeric textual

criticism in the sixth and fifth centuries BC', in F. Montanari (ed.), Omero tremila anni dopo: atti del congresso di Genova, 6-8 luglio 2000 (Rome) 105-36

Cook, E.F. (1995) The Odyssey in Athens: Myths of Cultural Origins (Ithaca and London)

Cole, T. (1967) Democritus and the Sources of Greek Anthropology (Cleveland)

Decleva Caizzi, F. (1966) Antisthenis fragmenta (Milan)

Di Benedetto, V. (2007) 'Tracce di Antistene in alcuni scoli all'Odissea', in id. II richiamo del testo: contributi di filologia e letteratura, vol. IV. (Pisa) 1597-614 [= reprint of id. SIFC(1966) 38, 208-26]

Dillon, J.M. (1997) 'Plato and the Golden Age', in id. The Great Tradition: Further Studies in the Development of Platonism and Early Christianity(Aldershot) 2136 [reprint of Hermathena 153, 21-36]

Dilts, M.R. (1971) Heraclidis Lembi excerpta politiarum (Durham, NC) Dougherty, C. (2001) The Raft of Odysseus: The Ethnographic Imagination of Homer's Odyssey (Oxford and New York)

Dümmler, F. (1882) Antisthenica (Berlin)

Dušanić, S. (1990) Историл и политика у Платоновим Законима [History and Politics in Plato's Laws] (Belgrade) [in Serbian with English summary; non vidi] England, E.B. (1921) The Laws of Plato, 2 vols. (Manchester)

Farrar, C. (2013) 'Putting history in its place: Plato, Thucydides and the Athenian politeia', in V. Harte and M. Lane (eds), Politeia in Greek and Roman Philosophy (Cambridge) 32-56

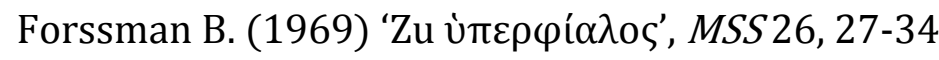

Gagarin, M. (2008) Writing Greek Law (Cambridge) 
Gaudin, C. (1981) 'Eúń $\theta \varepsilon ı \alpha$ : la théorie platonicienne de l'innocence', RPhilos 151, $145-68$

Giannantoni, G. (1990) Socratis et Socraticorum Reliquiae, 4 vols. (Naples)

Graziosi, B. (2002) Inventing Homer: The Early Reception of Epic (Cambridge)

Guggenheim, M. (1901) 'Antisthenes in Platons Politeia', Philologus 60, 149-54

— (1902) 'Studien zu Platons Idealstaat (Kynismus und Platonismus)', Neue

Jahrbücher für das klassiche Altertum, Geschichte und deutsche Literatur 9, 521-

39

Halliwell, S. (2000) 'The subjection of muthos to logos: Plato's citations of the poets', $C Q 50,94-112$

Hansen, M.H. (1991) The Athenian Democracy in the Age of Demosthenes:

Structures, Principles, and Ideology (Oxford)

Hölkeskamp, K.-J. (1992) 'Arbitrators, lawgivers and the "codification of law" in archaic Greece', Mètis 7, 49-81

— (1993) 'Written law in archaic Greece', CCJ38, 87-117

Janko, R. (1992) The Iliad: A Commentary, Vol. IV, Books 13-16(Cambridge)

Jolivet, J.-Ch. (2005) 'Le monde des Cyclopes, figure d'un monde archaïque:

exégèse homérique et retractatio de la Cyclopie dans I'Enéide', in J.P. Schwindt

(ed.), La représentation du temps dans la poésie augustéenne/Zur Poetik der

Zeit in augusteischer Dichtung (Heidelberg) 43-70

Kim, L. (2010) Homer Between History and Fiction in Imperial Greek Literature

(Cambridge)

Kullmann, W. (1991) 'Man as a political animal in Aristotle', in D. Keyt and F.D.

Miller (eds) A Companion to Aristotle's Politics (Cambridge, MA and Oxford) 94- 
117 [reprint of 'Der Mensch als politisches Lebewesen bei Aristoteles', Hermes 108 (1980) 419-43]

Labarbe, J. (1949) L'Homère de Platon (Liège)

Laks, A, (2000) 'The Laws', in C. Rowe and M. Schofield (eds), The Cambridge History of Greek and Roman Political Thought (Cambridge) 258-92

- (2005) Médiation et coercition: pour une lecture des Lois de Platon

(Villeneuve d'Ascq)

Lane, M. (2013a) 'Platonizing the Spartan politeia in Plutarch's Lycurgus', in V. Harte and M. Lane (eds), Politeia in Greek and Roman Philosophy (Cambridge) $57-77$

— (2013b) 'Lifeless writings or living scripts? The life of law in Plato, middle Platonism, and Jewish Platonizers,' Cardozo Law Review34, 937-64.

Lovejoy, A.O. and Boas, G. (1965) Primitivism and Related Ideas in Antiquity, with a Supplementary Essay by W.F. Albright and P.-E. Dumont (New York) [1935 original]

Luzzatto, M.T. (1996) 'La polytropia di Odisseo da Antistene a Porfirio', Elenchos $17,275-357$

Manfredini, M. and Piccirilli, L. (1980) Plutarco: le vite di Licurgo e di Numa (Milan)

Marasco, G. (1978) 'Aristotele come fonte di Plutarco nelle biografie di Agide e Cleomene', Athenaeum n.s. 56, 170-81

Marincola, J. (2007) 'Odysseus and the historians', Syllecta Classica 18, 1-79

Martin, R. (2013) 'The rhetoric of rhapsody in Plato's Laws' in A.-E. Peponi (ed.), Performance and Culture in Plato's Laws (Cambridge and New York) 313-38 Mayhew, R. (2008) Plato: Laws 10, Translation with Commentary(Oxford) 
Millender, E.G. (2001) 'Spartan literacy revisited', CA 20, 121-64

Mitscherling, J. (2005) 'Plato's misquotation of the poets', CQ55, 295-8

Montiglio, S. (2011) From Villain to Hero: Odysseus in Ancient Thought (Ann Arbor)

Morgan, K. (2012) 'Plato and the stability of history', in J. Marincola, L. LlewellynJones, C. Maciver (eds), Greek Notions of the Past in the Archaic and Classical Eras: History Without Historians (Edinburgh) 227-52

Morrow, G.R. (1960) Plato's Cretan City: A Historical Interpretation of the Laws (Princeton)

Müller, R. (1987) Polis und res publica: Studien zum antiken Gesellschafts- und Geschichtsdenken(Weimar).

Nagle, D.B. (2006) The Household as the Foundation of Aristotle's Polis (Cambridge and New York)

Nightingale, A.W. (1993) 'Writing/reading a sacred text: a literary interpretation of Plato's Laws', CP88, 279-300

- (1999) 'Historiography and cosmology in Plato's Laws', AncPhil 19, 299-326

Ostwald, M. (1986) From Popular Sovereignty to the Sovereignty of the Law. Laws, Society, and Politics in Fifth-Century Athens (Berkeley and Los Angeles) Panno, G. (2007) Dionisiaco e alterità nelle Leggi di Platone: ordine del corpo e automovimento dell'anima nella città-tragedia(Milan)

Pébarthe, C. (2006) Cité, démocratie et écriture: histoire de l'alphabétisation d'Athens à l'époque classique (Paris)

Pépin, J. (1993) 'Aspects de la lecture antisthénienne d'Homère', in M.-O. GouletCazé and R. Goulet (eds), Le cynisme ancien et ses prolongements: actes $d u$ colloque international du CNRS (Paris, 22-25 juillet 1991) (Paris) 1-13 
Piette, A. (1985) 'Platon et "la différence anthropologique"', ÉtClass 53, 355-66

Pontani, F. (2005) Sguardi su Ulisse: la tradizione esegetica greca all Odissea

(Rome)

Rowe, C. (2007) 'Plato and the Persian Wars', in E. Bridges, E. Hall and P. J.

Rhodes (eds), Cultural Responses to the Persian Wars (Oxford) 85-104

Saunders, T.J. (1995) Aristotle: Politics, Books I and II(Oxford)

Schofield, M. (2006) Plato: Political Philosophy(Oxford)

- (2010) 'The Laws' two projects', in C. Bobonich (ed.), Plato's Laws: A Critical Guide (Cambridge) 12-28

- (2013) 'Friendship and justice in the Laws', in G. Boys-Stones, D. El Murr and C. Gill (eds), The Platonic Art of Philosophy (Cambridge) 283-97

Schöpsdau, K. (1994) Platon: Nomoi (Gesetze), Buch I-III(Göttingen)

- (2003) Platon: Nomoi (Gesetze), Buch IV-VII(Göttingen)

Scodel, R. (2005) 'Odysseus’ ethnographic digressions', in R.J. Rabel (ed.), Approaches to Homer: Ancient and Modern (Swansea) 147-65

Schrader, H. (1890) Epilegomena, in Porphyrii Quaestionum Homericarum ad Odysseam pertinentium reliquiae (Leipzig)

Schütrumpf, E. (1991) Aristoteles: Politik, Buch I (Darmstadt)

Segal, C. (1994) Singers, Heroes, and Gods in the Odyssey (Ithaca, NY)

Solmsen, F. (1969) Review of Cole 1967, Phoenix 23, 399-402

Taylor, C.C.W. (2007) 'Nomos and phusis in Democritus and Plato', Social Philosophy and Policy 24, 1-20

Thomas, R. (2010) Review of Pébarthe 2006, Klio 92, 495-99

Trapp, M.B. (1997) Maximus of Tyre: The Philosophical Orations (Oxford)

Tulli, M. (1994) 'La storia impossibile nel Politico di Platone', Elenchos 15, 13-21 
— (2003) 'Omero nel III libro delle Leggi', in S. Scolnicov and L. Brisson (eds), Plato's Laws: From Theory into Practice. Proceedings of the VI Symposium Platonicum: Selected Papers (Sankt Augustin) 227-31

van der Valk, M. (1949) Textual Criticism of the Odyssey (Leiden)

Vidal-Naquet, P. (1986) 'Land and sacrifice in the Odyssey: a study of religious and mythical meanings' (tr. R.L. Gordon, rev. A. Szegedy-Maszak), in id. The Black Hunter: Forms of Thought and Forms of Society in the Greek World (Baltimore and London) 15-38 [Fr. orig. 1981]

Weil, R. (1959) L'archéologie de Platon (Paris)

Wilke, B. (1997) Vergangenheit als Norm in der platonischen Staatsphilosophie (Stuttgart)

Yunis, H. (2011) Plato: Phaedrus (Cambridge)

\footnotetext{
*My sincerest thanks to Giovanbattista D’Alessio, Filippomaria Pontani, Malcolm Schofield and the anonymous JHS referees for their constructive criticism of earlier drafts of this article. Special thanks are also due to the Cambridge B Caucus, under whose auspices this paper began to take form and to Carol Atack for allowing me to read her unpublished Cambridge PhD dissertation. I alone am responsible for what I have written.

${ }^{1}$ Barker (1918) 307.
} 
${ }^{2}$ For the importance of the historical digression of book 3 in the Laws as a whole, see above all Schofield (2010) 18-21, 25-26 and (2013) 288-96. On Plato's 'mythical history' in Laws 3, see Morgan (2012), Nightingale (1999) (emphasising the underlying thematic continuity between book 3 and the cosmological section of book 10). On Plato's reflections on history in book 3 as an indirect critique of a distinctly Thucydidean view of the goals of historical enquiry, see Farrar (2013) and Tulli (2003). For Plato re-reading Thucydides in the 'archaeological' section of book 3, see already the pioneering work by Weil (1959). All the quotation from the Laws in this article are taken from the Budé edition.

3 The most detailed treatment of Plato's engagement with Doric, and most specifically Spartan, traditions in this section is that by Schöpsdau (1994) 383451; cf. also Wilke (1997) 177-79 and Morgan (2012) 244-52 on how the 'point of transition' to history proper (the emergence of the Doric ع $\varepsilon$ vvo ), in book 3 , is also 'a point of continuity' with the previous quasi-mythical section: in the narrative of the Athenian Stranger the example of historical Sparta provides the explanation for the 'congruence between history and theory' he advocates. ${ }^{4}$ On Plato's subversive exploitation of traditional stereotypes in both the Persian and Athenian section of book 3 about mixed constitutions, see Schofield (2013) 288-97, Farrar (2013) and Rowe (2007).

${ }^{5}$ See esp. the work by Cole (1967) 97-106, with Solmsen's caveats , (1969) 402. For a sceptical view of Plato's dependence on Democritus' anthropology in the 'archaeology’ of Laws 3, see more recently Müller (1987) 214 and Schöpsdau (1994) 358 with further bibliography. On the importance of 'necessity' and 
'need' in Democritus' anthropological account of the evolution of humankind and on nomoi as 'developed by a process of natural necessity, the necessity for human beings to develop co-operative strategies enabling them to achieve their natural goals despite their natural limitations', see above all Taylor (2007) 1-9 (the quotation is from p. 9).

${ }^{6}$ On the unresolved tension between the fixed, written form of the law and the proems in the Laws, see above all Laks (2000) and Bertrand (1999) 229-46, 326-36. For Plato's qualified political rehabilitation of writing in connection with lawgiving in both the Laws and the Statesman and its relationship to the Phaedrus'critique of writing qua writing, see recently the perceptive analysis by Lane (2013a) and (2013b).

${ }^{7}$ Martin (2013) 324-25 touches upon this issue (he brings in Plut. Lyc. 4.2-4 with reference to Megillus' reply), but does not elaborate on it (see below).

${ }^{8}$ Cf. $3,682 \mathrm{e} 8-11$ on the digressive nature of the excursus of book 2 about music and drunkenness.

${ }^{9}$ I retain the transmitted $\mu \varepsilon \tau \alpha \beta \alpha$ ívovo $\alpha \nu$ versus Boeckh's emendation $\mu \varepsilon \tau \alpha \beta \alpha \iota v o v \sigma \tilde{\omega} v$ : see England (1921) I 344.

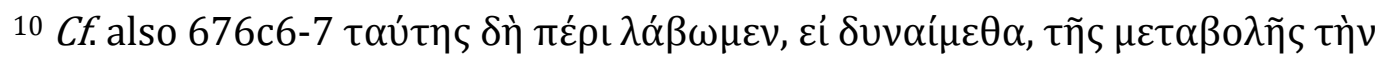

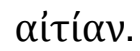

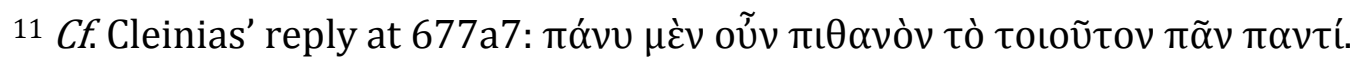

12 On the different handling of these myths of disaster by Plato in the Statesman and the Timaeus/Critias, see Morgan (2012) 228-33 and Dillon (1997). For the various accounts of human evolution offered by Plato across his corpus, see Piette (1985) and Lovejoy and Boas (1965) 155-68. 


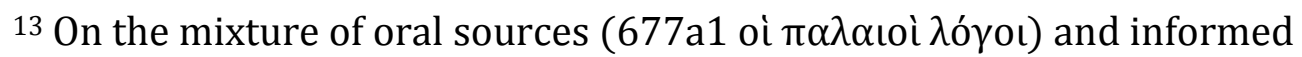

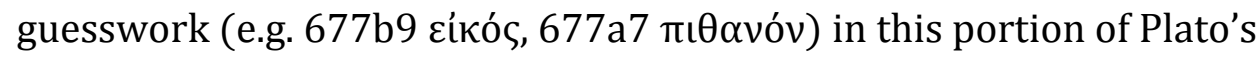
'archaeology', and its relation to Thucydides' and Herodotus' methods of inquiry for the most distant past, see Weil (1959) 42-54; cf. also Tulli (2003).

14 The whole argument is presented as an argument from probability rather than a syllogistic demonstration.

15 For vegetarianism, markedly absent in the Athenian Stranger's version of the myth of origin, as a typical feature of the Golden Age, see Vidal-Naquet (1986); on the Cyclopes as prototypical example of pastoralist vegetarians and, at the same time, cannibals, see Bakker (2013) 53-73.

16 On Plato's shifting conceptualization of عúṅ $\theta \varepsilon \iota \alpha$ across his oeuvre, see Gaudin (1981). That at 679c2-3 the Athenian Stranger qualifies it as 'the so-called simplicity' indicates the extent to which Plato is willing to go to bestow a positive moral outlook to this primitive state of humankind.

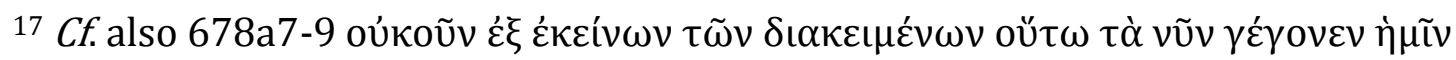

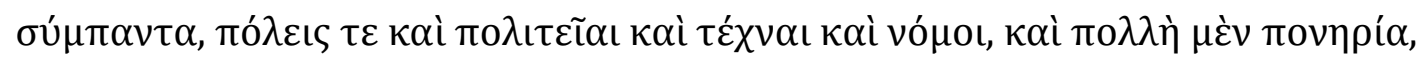

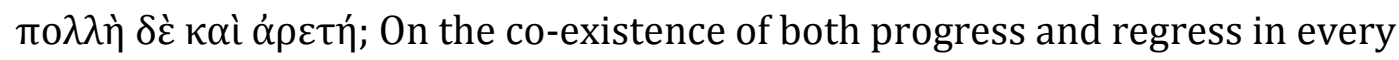
stage of human history in the narrative of the Athenian Stranger, see Nightingale (1999) 301 and 304-06.

18 See Schofield (2006) 203 on the positive moral characterization of these early communities.

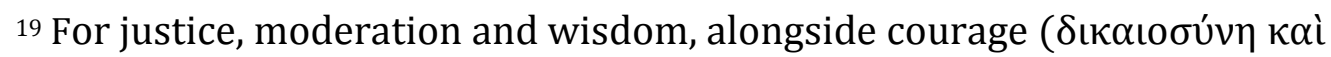

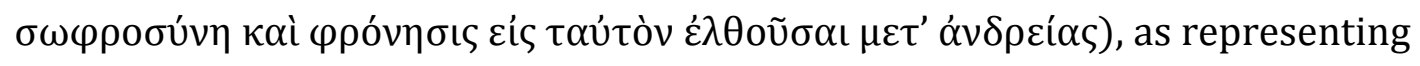
the $\sigma v^{\prime} \mu \pi \alpha \sigma \alpha \alpha \rho \varepsilon \tau \eta^{\prime}$ that is the goal of 'true' legislation, see 1, 630a8-b2. For the 


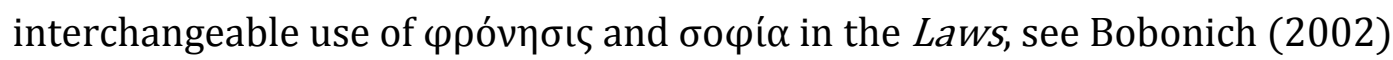
197-201 and esp. 520-21 n. 124.

${ }^{20}$ For Homer as the 'first historian', see the overview by Kim (2010) 22-46 and Graziosi (2002) 118-21.

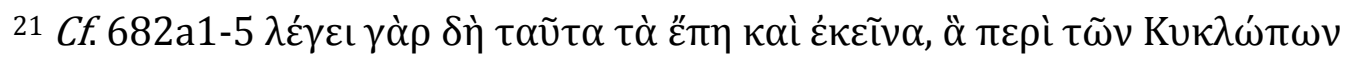

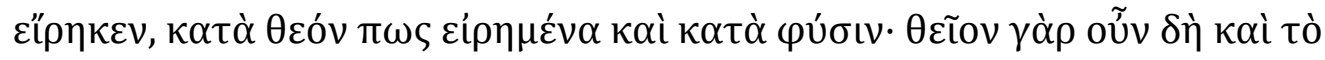

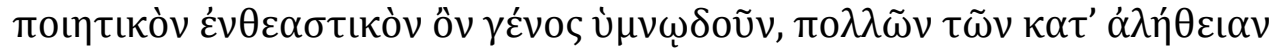

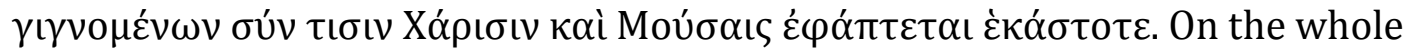
passage, see Schöpsdau (1994) 373-74, especially 373 on the heavily conditional validation of poets' access to truth: 'Die Aussage in a3-5 besagt natürlich nicht, dass Dichter kraft göttlicher Inspiration immer und ausschliesslich Wahres verkünden, sondern nur, dass sie, falls sie Wahres sagen (was nicht immer der Fall ist), dies jeweils göttlicher Inspiration verdanken (und nicht wirklichem Wissen)'. Notice that already at $680 \mathrm{~d} 4-5$ Homer is said to $\sigma u \mu \mu \alpha \rho \tau u \rho \varepsilon \tilde{v}$ what

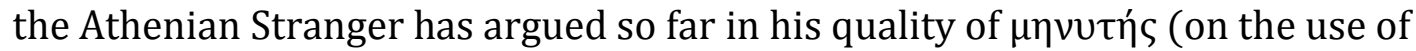
this word by Plato, with specific reference to poets and their relation to the

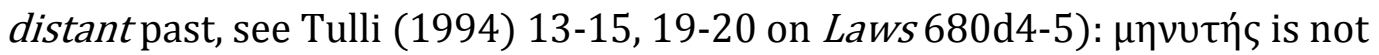
someone who discovers or creates anew something which did not exist before but someone who 'reveals' something which was already there but kept hidden and obscure. That is, poetry is represented here by Plato not as an independent source of knowledge per se but simply as a further piece of supporting evidence, circumscribed and conditional, which confirms a 'truth' alreadyobtained through another medium, i.e. philosophical inquiry. For the poet as 'witness' in Plato, see also Halliwell (2000) 98 n. 19. 
22 I retain the ms reading $\alpha \tilde{i} \zeta$ and understand the antecedent of the relative to be

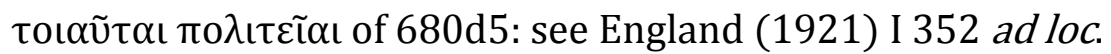

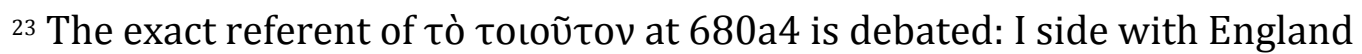
(1921) I 351 ad loc. in translating it 'such a thing as a law' rather than, by synecdoche, 'such a thing as a lawyer'. See also the recent translation by Brisson and Pradeau (2006) I 169: 'N'est-il pas vrai que ... à l'époque, on n'avait aucun besoin de se donner quelche chose de semblable à des lois?'

${ }^{24}$ For the Homeric image, see already Weil (1959) 72 ad loc. with parallels.

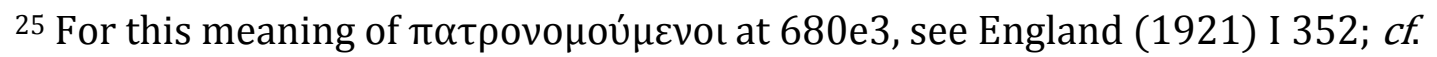
also Weil (1959) 72 ad loc.

${ }^{26}$ The epexegetical value of $\kappa \alpha$, explaining the ambiguous $\pi \alpha \tau \rho o v o \mu o u ́ \mu \varepsilon v o \iota$, has been kindly pointed out to me by the anonymous referee.

27 Cf. e.g. England (1921) vol. I ad loc; Schöpsdau (1994) 367 has useful observations on the 'constitutional' profile of the $\delta u v \alpha \sigma \tau \varepsilon i ́ \alpha$ evoked by the Homeric quotation but is not interested in asking why Plato introduces the

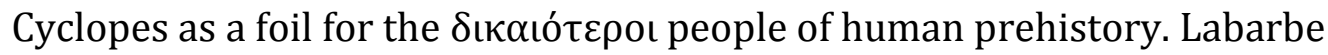
(1949) 236-38 discusses the textual variants of the Homeric texts offered by the Platonic manuscript tradition.

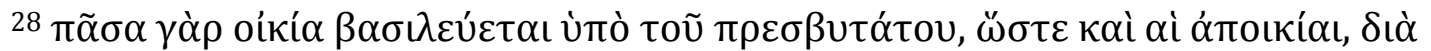

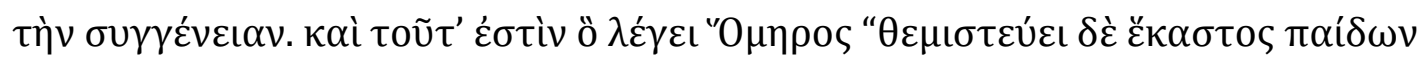

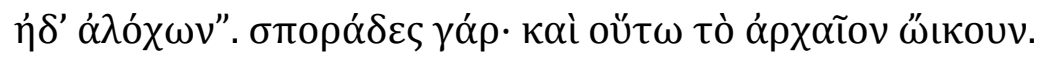

${ }^{29}$ Cf. e.g. Weil (1959) 69-70; on Aristotle's partial dependence on the Laws passage, see Kullmann (1991) 96-97; Schütrumpf (1991) 200-01; Saunders

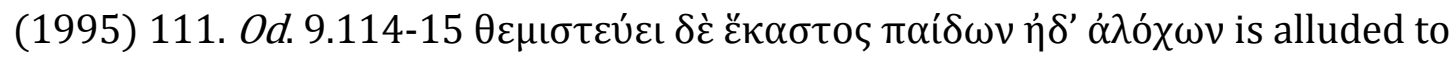




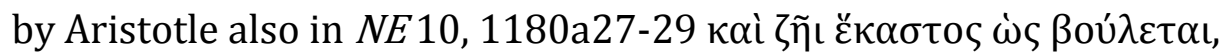

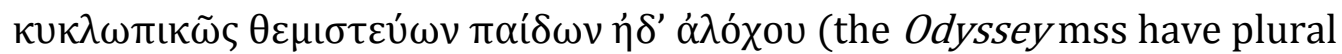
$\alpha \lambda o_{\chi} \chi \omega v$ ) but with a very different function (as an example of neglect on the part of the state to foster educational practices). The value-judgment at $N E 10$, 1180 a27-9 is negative: the Cyclopean way of life is mentioned to typify those states that do not engage seriously as moral educators of their citizens since infancy but neglect their duty about upbringing. 30 Dušanić (1990) 375 as reported by Schöpsdau (1994) 367. I could not get hold of the Serbian version but Schöpsdau provides a detailed account of Dušanić's interpretation of this passage.

31 Dillon (1997) 31. Dillon, referring to Od. 9.106-111 (lawlessness and absence of agricultural toil), states that ' $[\mathrm{t}]$ he Cyclopes, then, are something of an embarrassment ... for anyone concerned to promote a positive picture of the Golden Age ... There seems to me therefore to be an element of irony in Plato's bringing them into the discussion here, as the description of their life seems to highlight the profound ambiguities of Golden Age living.'

32 On the irony of 680c-d, see Martin (2013) 322-25 and 333 (Homer as a cultural possession monopolized by Athens only). For my reading of Megillus' reply at 680c6-d3, see below.

${ }^{33}$ A strategy, of course, well attested in the Platonic corpus, when the philosophical argument and context so require: see the fundamental contribution by Halliwell (2000). For intentional (mis)quotations of Homer in the Laws, see recently Mitscherling (2005) (on Od.17.322-3 at 6, 777a1-2). 
${ }^{34}$ Both interpretations had widespread currency in antiquity: for the former (absence of agricultural labour), see Eustath. ad Odyss. I, 1617 ll. 30-43 Stallbaum drawing on Strabo 11.4.3 (cf. also Strabo 13.1.25, referring to our passage of the Laws; on these passages and CPGII, 182, see Di Benedetto (2007) 1608 n. 24); for the latter, see $C P G$ II, A IV 92b and M V 44. For a further twist on

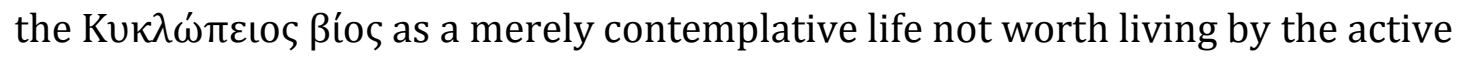
philosopher, see Maximus Tyr. Diss. 15.7.4 Trapp.

35 For the mixing of the traditions, cf. the Statesman's account of the lawgiver's art (e.g. Plt. 306aff.).

36 Differently from England (1921) I 354 ad 681c9-10, I am inclined to take عis tò

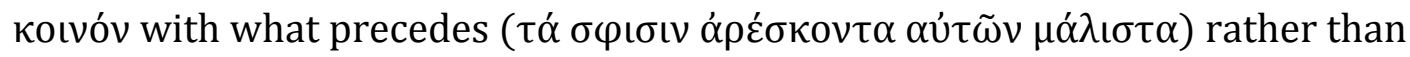

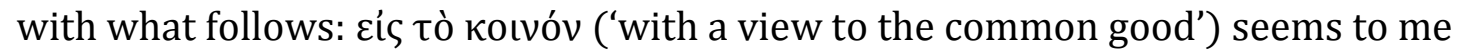
to qualify the overriding criterion by which the selection and review of customs is to be made.

${ }^{37}$ For this act of political negotiation to bridge the gap between mere social aggregation of households and political community of polis, see Nagle (2006) 23. 38 On the complex semantic range covered by the word nomos and its shift from a descriptive ('social norm') to a 'prescriptive' function in the fifth BC, see Ostwald (1986) 86-108. For archaic law-making stricto sensu (as opposed to traditional 'nomological' knowledge of preliterate societies) presupposing the existence of the medium of writing as a necessary condition, see Gagarin (2008) 6, 9 and 39-45 and Bertrand (1999) 60-62; cf. also Hölkeskamp (1993) 98-99 and (1992) 64-66. On the importance of the connection made by the Athenian Stranger between the rule of law proper and writing in our passage of the Laws, 
see Morrow (1960) 547. On the relationship between 'unwritten customs' and 'written laws' as envisaged in the second-best city of Magnesia, see 7.793a9-c5 (on which see Bernard (1999) 60).

${ }^{39}$ For the Cyclopeia of $O d y s s e y 9$ as 'contribut[ing] to the ethnographic program of the Apologoi by representing Greek civilization as the goal of this evolutionary process', see Cook (1995) 71-72. On Odysseus as the first 'ethnographer' and 'historian', see Marincola (2007). For the varia lectio vó $\mu$ ov ع̋ $\gamma v \omega$ (vs. the vulgata

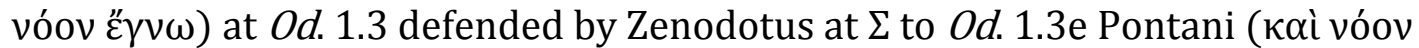

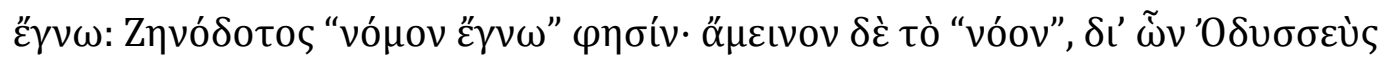

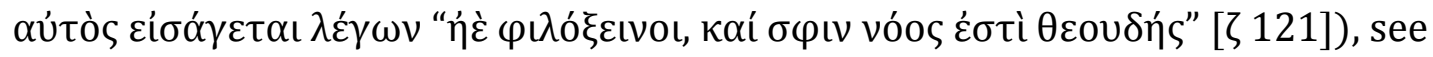
van der Valk (1949) 97.

${ }^{40}$ For present purposes the scholia to the Odysseyare quoted from Schrader's edition rather than Dindorf's (see Di Benedetto's observations, (2007) $1597 \mathrm{n}$. 1). For clarity's sake I have also added, where available, the numeration of the corresponding fragment of Antisthenes according to Giannantoni's SSR edition.

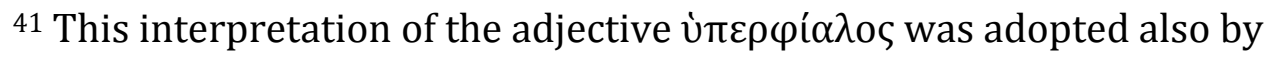
Aristarchus: $c f$ scholia A to II. 15.94b with Di Benedetto (2007) 1604-05. (On the

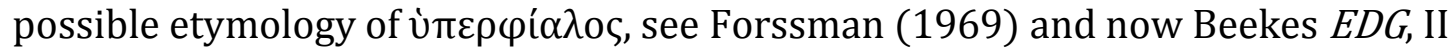

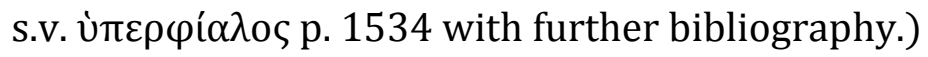

${ }^{42}$ For the Antisthenic (rather than Aristarchean) paternity of the charitable reading of $\alpha \theta \varepsilon \mu i ́ \sigma \tau \omega \nu$ at $O d$. 9.106, see the arguments by Di Benedetto (2007) 1604-05. 
43 For this defence of the Cyclopes' behaviour towards the Phaeacians, their own kin, and how this element of the interpretatio homerica goes back to Antisthenes too, see Di Benedetto (2007) 1606-07.

44 The same explanation for the behaviour of the Cyclopes towards the Phaeacians is given also by Eustathius: see Di Benedetto (2007) 1608-09. ${ }^{45}$ For an up-to-date status quaestionis on the presence of Antisthenic material in the Homeric scholia, see Pontani (2005) 30 with n. 29 with further bibliography (Di Benedetto (2007) remains fundamental). For Antisthenes as Homeric critic, see also Montiglio (2011) 20-37, Giannantoni, SSR IV, 331-37, Brancacci (1990) 45-75 (66-69 on Od. 9.106), Pépin (1993) and more generally Luzzatto (1996). 46 See e.g. Dümmler (1882) 3-4 on the 'city of pigs' in Resp. 2.372c-e and Guggenheim (1901) and (1902(. For Plato's engagement with Antisthenes in the Hipp. min., see the balanced approach by Luzzatto (1996) 291-99. 47 Guggenheim (1902) 527 n. 2 briefly discusses Laws 3, 694c with reference to the paradigmatic positive role (resisted by Plato) that the historical figure of Cyrus acquires among later Cynics. Dümmler (1882) 22 does quote the two Aristotelian passages mentioned above (Politics $1252 \mathrm{~b} 22-24$. and $N E 10 \mathrm{~m}$ 1180a27-29) but ignores Plato's Laws (which Politics 1252b22-24 certainly presupposes). Neither Decleva Caizzi nor Giannantoni mention the Laws passage in their Antisthenes editions and commentaries. To the best of my knowledge, the only exception is Atack (2014) 184 who observes that in Laws 678a-680e 'the early family-based societies recall the Homeric Cyclopes, and Antisthenes' arguments that theirs was a just society'; Atack however does not elaborate on the connection nor does she highlight the link between 'natural' justice and 
absence of written vó $\mu$ os. Jolivet (2005) 52 does not consider the possibility of Plato's dependence on Antisthenes at Laws 3.680b-c.

48 See Hansen (1991) 311-12 on the contemporary cultural climate of the newly restored democracy after 401 down to $322 \mathrm{BC}$, and its emphasis on the over-all importance of written law.

${ }^{49}$ See most recently Lane (2013a) and (2013b); cf. already Morrow (1960) 547:

'Plato recognizes the importance of written law in his account of the development of political society (680a-681d), and the very purpose of the Laws is to provide such a known and standing law for the citizens of his state.'

50 Panno (2007) 260 and Bobonich (1996) 253 with n. 8 on this passage. For the self-referential character of the Laws as text, namely as a written law-code, see Adomènas (2001) (esp. 34-35 on 7.811b-812a). On the 'sacred' aura surrounding the written text of the law-code in the Laws, see Nightingale (1993). 51 On the sense of $\eta \rho \varepsilon \mu \varepsilon \tilde{~}$ 'stand still, stand as they are', see England (1921), II 459-60 ad loc.

52 See the scepticism of Bobonich (1996) 269-73 and Mayhew (2008) 97-98.

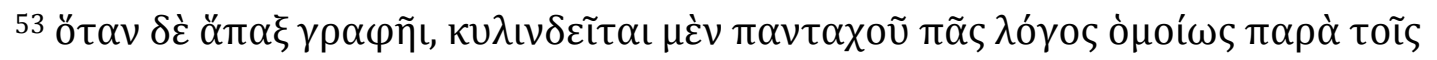

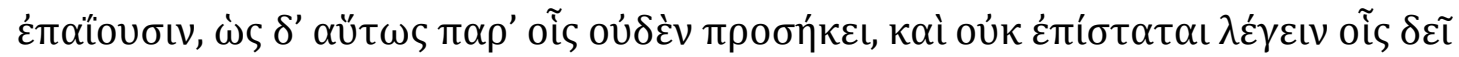

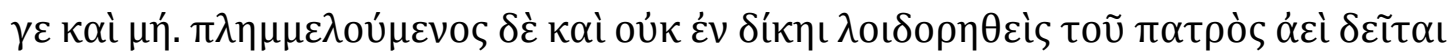

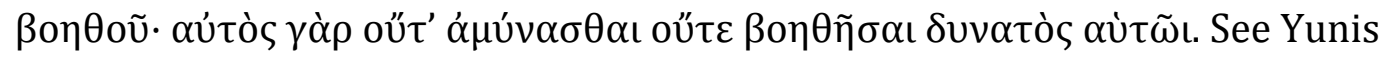
(2011) 230-31.

54 This point does not figure in Lane's otherwise illuminating treatment of the issue (Lane (2013a) and (2013b)). Cf. also 9, 858d-e: in the second-best city the

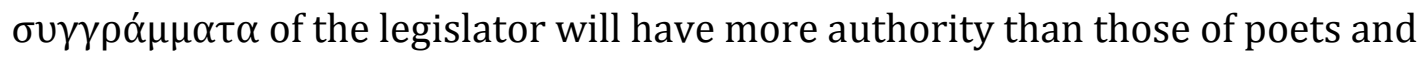


other writers: d1-4; only the legislator, among the writers, must advise about what is beautiful, good and just: d5-9; of all the writings available in the cities,

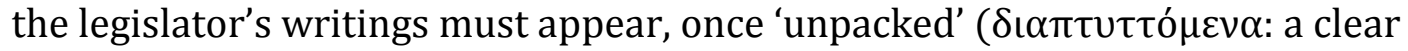
recognition that written law needs expounding and must be internalized via the proems to the laws), as the most beautiful and best: e4-7).

55 At 4, 719d3 the soul of the prototypical Magnesian to which admonition and exhortation, through the proems to the laws, will be directed, will not be 'entirely

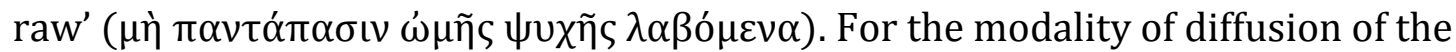
law (written and oral) within Magnesia: cf. Panno (2007) 258-63 and 269-82, Laks (2005) 129-46, and Bertrand (1999) 98-103, 229-32.

56 Cf. Morrow (1960) 547 who observes that Plato is willing to 'reduce to writing - not in the forms of laws, but as admonition and advice - as much as possible of the "unwritten customs" or moral rules that he expects his citizens to observe'. See Schöpsdau (2003) 625 on the relationship between $\alpha \beta \gamma \rho \alpha \varphi \alpha$ vó $\mu \mu \alpha$ and written law with relation to the upbringing and education of children at 7 , 793a-d.

57 Martin (2013) 322.

${ }^{58}$ Martin (2013) 322 and 330 for the paradoxical formulation of a 'hidden centrality'; cf. also (2013) 326: 'local traditions are thus immediately co-opted or trumped by the Athenian through the use of Homer as an Athenian cultural weapon'. ${ }^{59}$ Graziosi (2002) 217 observes that 'Plutarch ... typically interprets the statement "Lycurgus brought the poems to the Peloponnese" as a reference to the writing down of the Homeric poems', whereas 'earlier sources link the 
expression "to take poems to a place" with the institution of rhapsodic performances'.

60 Martin (2013) 324 and 325.

${ }^{61}$ See Piccirilli in Manfredi and Piccirilli (1980) 226-27 for the sources. For the cultural assumptions underlying the two versions, see Graziosi (2002) 219-20. ${ }^{62}$ Cf. Ephorus (4th BC) FGrH 70 F 149. $19=$ Strabo 10.4.19, Apollodorus of Athens (2nd BC) FGrH244 F63b = Clem. Al. Strom. I 117.3 .

63 On the monopoly of East Ionia on early epic texts, see Cassio (2002) 111 with n. 30; on Creophylus and the Creophylei, see Graziosi (2002) 218. A specific Athenian tradition had it that Homer arrived first at Athens via the rival guild of the Homeridai of Chios: see Graziosi (2002) 217-28.

${ }^{64}$ Graziosi argues for a fifth century BC Athenian origin (clearly in an antiSpartan function: Graziosi (2002) 219-20), whereas Janko (1992) 31 n. 50 argues for a genuine sixth-century BC Spartan tradition (in the sixth century BC Sparta and Samos were close allies).

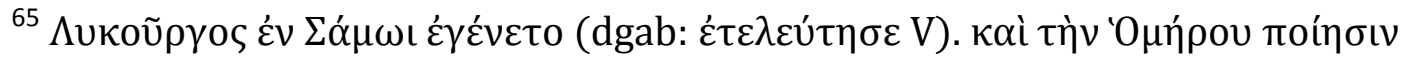

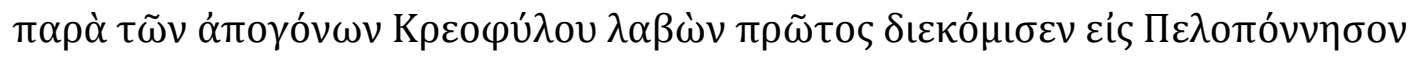
(the text is quoted here according to Dilts' edition). Marasco traces the origin of this strand of the tradition back to Aristotle, $c f$. Marasco (1978) 175. For later sources, see Piccirilli in Manfredi and Piccirilli (1980) 227.

66 The indulgent and luxurious way of life of the Phaeacians is routinely pointed out by Homeric scholarship at least since the fourth century BC (see Di Benedetto (2007) 1607 n. 21 for the ancient sources) but I could not find 
anywhere else a direct association of Homer's poetry tout court and an Ionian style of life.

67 Weil (1959) 70-71 ad loc. See also Schöpsdau (1994) 368 ('eine ausdrückliche Zurückführung ihrer gesetzlosen Lebensweise auf ihre Rohheit findet sich nicht in der Odyssee'), who then goes on to suggest that perhaps Plato 'einfach aus

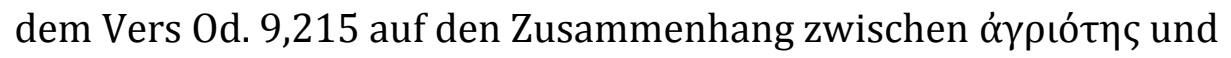
Gesetzlosigkeit schloss'.

${ }^{68}$ Cf. the Athenian Stranger's implicit 'correction' of Megillus' inference at 680d

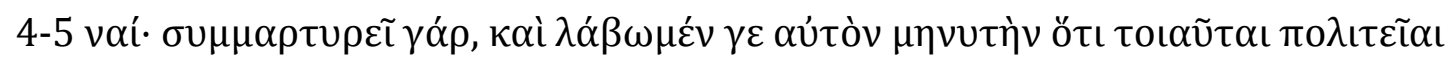

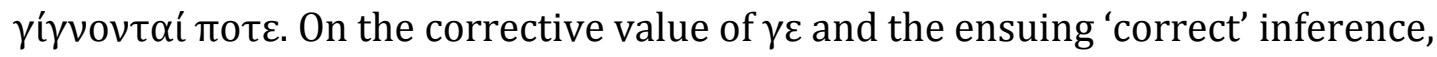
see already Weil (1959) 71 ad loc.

${ }^{69}$ On Spartan literacy, see Millender (2001), followed by Pébarthe (2006) 38-42 (but see the caveats of Thomas (2010) 496); cf. also Bertrand (1999) 71-82. It is a matter of fact that across his oeuvre Plato twice makes explicit reference to Lycurgus as a lawgiver who promulgated written laws: Phaedrus 258c1-2 (logographos, i.e., in the context, 'a writer of laws', see Yunis (2011) 173) and Laws 9, 858e3-4. This point is rightly highlighted by Lane (2013a) 59, 64-65; cf. esp. p. 65: 'This is positive support for taking the absence of any classical source for a Lycurgan ban on written law to be more than merely an accident of transmission.'

${ }^{70}$ Scodel (2005) 150-52 and 158 on how Odysseus' 'unrealistic knowledge' in the ethnographical digression of the apologoi 'depends on [the apologoi's] participation in an ethnographical subgenre ... the poet gives his own knowledge 
to the internal narrator, who has an authority that is internally motivated as autopsy but in practice belongs to the genre'.

71 Martin (2013) 323. 